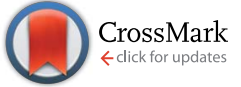

Cite this: RSC Adv., 2017, 7, 4710

Received 23rd November 2016 Accepted 27th December 2016

DOI: 10.1039/c6ra27204e

www.rsc.org/advances

\section{Catalytic performance of gallium oxide based- catalysts for the propane dehydrogenation reaction: effects of support and loading amount}

\begin{abstract}
Chun-Tao Shao, Wan-Zhong Lang, ${ }^{*}$ Xi Yan and Ya-Jun Guo*
The different materials (ZSM-5, SBA-15, $\gamma-\mathrm{Al}_{2} \mathrm{O}_{3}$ and $\mathrm{SiO}_{2}$ ) were used as supports for $\mathrm{Ga}_{2} \mathrm{O}_{3}$-based catalysts for the propane dehydrogenation reaction, and the effect of $\mathrm{Ga}_{2} \mathrm{O}_{3}$ content (1-9 wt\%) for $x \mathrm{Ga}_{2} \mathrm{O}_{3} / \mathrm{SBA}-15$ catalysts on the catalytic activity was discussed. It is found that the supports determine the porous features, the state and dispersion of Ga species, and the acid-base properties of the corresponding catalysts. The existence of strong acid sites in catalyst can lead to more well-dispersed Ga species. The satisfied catalytic performances are obtained over $5 \mathrm{Ga}_{2} \mathrm{O}_{3} / \mathrm{ZSM}-5$ and $5 \mathrm{Ga}_{2} \mathrm{O}_{3} / \mathrm{SBA}-15$ catalysts. Among the $\mathrm{Ga}_{2} \mathrm{O}_{3}$-based catalysts with different supports, the $5 \mathrm{Ga}_{2} \mathrm{O}_{3} / \mathrm{ZSM}-5$ sample exhibits the highest catalytic activity, which possesses the maximum well-dispersed gallium species and high dehydrogenation efficiency gallium ions $\left(\mathrm{Ga}^{\delta+}\right.$ cations, $\left.\delta<2\right)$, and the $5 \mathrm{Ga}_{2} \mathrm{O}_{3} / \mathrm{SBA}-15$ catalyst exhibits the highest catalytic stability. Furthermore, as for the $x \mathrm{Ga}_{2} \mathrm{O}_{3} / \mathrm{SBA}-15$ samples, the $5 \mathrm{Ga}_{2} \mathrm{O}_{3} / \mathrm{SBA}-15$ sample exhibits the best catalytic performance. The initial propane conversion and propylene selectivity are above $32.0 \%$ and $90.0 \%$ respectively, and a final propane conversion of $17.0 \%$ is obtained after $30 \mathrm{~h}$ reaction. With the increase of Ga loading, the Ga species are easily agglomerated and destroy the structural integrity of the SBA-15 support, which is unfavorable to the propane dehydrogenation reaction.
\end{abstract}

\section{Introduction}

Propylene is a major raw chemical for the petrochemical industry. In recent years, more attention has been paid to the catalytic dehydrogenation of propane to propylene because the growing demand for propylene is beyond the production capacity of conventional hydrocarbon steam cracking and catalytic cracking processes. ${ }^{\mathbf{1 - 3}}$ The catalytic dehydrogenation of propane is an endothermic process, which needs a relatively high reaction temperature to obtain a high propylene yield. Nevertheless, under such high temperatures, the undesirable side reactions such as hydrogenolysis, cracking and coke deposition are inevitable. ${ }^{\mathbf{4 , 5}}$

Currently, many studies are devoted to developing novel and potential catalysts in propane dehydrogenation (PDH), such as ceria-based catalysts, ${ }^{6}$ calcined hydrotalcite-supported platinum catalysts, ${ }^{7} \mathrm{Sn} / \mathrm{SiO}_{2}$ catalysts, ${ }^{8}$ Pd-based catalysts, ${ }^{9}$ mesoporous carbons, gallium oxide-based catalysts ${ }^{10,11}$ and so on. Among these, gallium oxide-based catalysts have been recognized as new promising alkane dehydrogenation materials due to their unique capability to activate hydrocarbon species and

The Education Ministry Key Laboratory of Resource Chemistry and Shanghai Key Laboratory of Rare Earth Functional Materials, Department of Chemistry and Chemical Engineering, Shanghai Normal University, 100 Guilin Road, Shanghai 200234, China. E-mail: wzlang@shnu.edu.cn; guoyajun@shnu.edu.cn; Fax: +86-2164321951; Tel: +86-21-64321951 excellent catalytic efficiency as compared to conventional $\mathrm{Cr}_{2} \mathrm{O}_{3}$ and $\mathrm{V}_{2} \mathrm{O}_{5}$-based catalysts. ${ }^{12-16}$ For instance, Nakagawa et al. ${ }^{\mathbf{1 4}}$ proposed that the commercial $\mathrm{Ga}_{2} \mathrm{O}_{3}$ had exceptionally high activity for the dehydrogenation of ethane to ethylene, and they found that $\beta-\mathrm{Ga}_{2} \mathrm{O}_{3}$ exhibited the highest dehydrogenation activity among all of the polymorphs due to its abundant surface acid sites.

The support effects of catalysts were also considered to be an important topic. Previous studies ${ }^{11,16-19}$ reported that the $\mathrm{Ga}_{2} \mathrm{O}_{3}$ species were dispersed on different supports including $\mathrm{TiO}_{2}$, $\mathrm{MgO}, \mathrm{Al}_{2} \mathrm{O}_{3}, \mathrm{ZrO}_{2}, \mathrm{ZSM}-5, \mathrm{HZSM}-48$ and MWW zeolites for alkane dehydrogenation reaction. Many literatures verified that acidity of support evidently influenced the catalytic performance of the supported catalysts. For example, Shen et al. ${ }^{\mathbf{2 0}}$ reported that the stability and selectivity of $\mathrm{Ga}_{2} \mathrm{O}_{3} / \mathrm{HZSM}-5$ catalyst in the propane dehydrogenation were enhanced by increasing the $\mathrm{Si} / \mathrm{Al}$ ratio of $\mathrm{HZSM}-5$ support. XU et al. ${ }^{16}$ reported that $\mathrm{Ga}_{2} \mathrm{O}_{3} / \mathrm{TiO}_{2}, \mathrm{Ga}_{2} \mathrm{O}_{3} / \mathrm{Al}_{2} \mathrm{O}_{3}$ and $\mathrm{Ga}_{2} \mathrm{O}_{3} / \mathrm{ZrO}_{2}$ showed better activity for the dehydrogenation of propane to propylene than $\mathrm{Ga}_{2} \mathrm{O}_{3} / \mathrm{SiO}_{2}$ and $\mathrm{Ga}_{2} \mathrm{O}_{3} / \mathrm{MgO}$ due to the more acid sites in medium to strong strength. Wang et al. ${ }^{19}$ revealed that Ga/ITQ-2 exhibited higher selectivity and better stability in propane dehydrogenation reaction as compared with those of Ga/MCM22, due to the higher surface area and relatively less strong acid sites.

Since gallium oxide-based catalysts were found to have good alkane dehydrogenation properties, ${ }^{\mathbf{1 4 , 1 5 , 2 1}}$ several investigations 
attempted to elucidate the reasons of high catalytic performance. The previous studies reported that the gallium oxides $\left(\mathrm{Ga}_{2} \mathrm{O}_{3}, \mathrm{GaO}^{+}\right)$were the most species presented on the catalyst after calcination and were readily reduced during pretreatment with hydrogen. ${ }^{1622-24}$ The various gallium species $\left(\mathrm{Ga}_{2} \mathrm{O}_{3}, \mathrm{GaO}^{+}\right.$ and $\mathrm{Ga}^{+}$) as active constituents exhibited different performances for light alkane dehydrogenation reaction. ${ }^{25}$ In addition, Nowak et al. ${ }^{26}$ also reported the dispersion of $\mathrm{Ga}_{2} \mathrm{O}_{3}$ species varied with different supports. However, the effects of supports on the state of gallium species have not been fully understood, especially the causes of these changes.

Among these support materials, alumina is extensively used as catalyst support due to its surface acidic properties and desirable textual properties. Nevertheless, the stability of catalyst is still not very satisfactory. ${ }^{27,28}$ As regards ZSM-5 zeolite, it has some particular physical properties such as unique threedimensional channels, relatively large surface area and adjustable $\mathrm{Si} / \mathrm{Al}$ ratio. Especially it can hinder the formation of large hydrocarbon molecules due to the unique framework and channel structure, which are beneficial to the catalytic stability. Therefore, ZSM-5 is widely used in propane dehydrogenation reaction. ${ }^{29,30}$ Besides, as advanced mesoporous materials, SBA15 and nano-silica are often employed as supports for catalysts. Generally, SBA-15 is characterized by its ordered porous structure, high specific surface area and high thermal stability, and the certain pore volume of mesoporous materials and the free of acid sites can greatly resist the formation of coke. ${ }^{31,32}$ Nano-silica also has the characteristics of large surface area, chemical stability and cheapness. ${ }^{33}$ It is obvious that the catalysts using different supports may show the distinctive catalytic properties. Hence it is necessary to discuss the influences of the different supports on the catalytic performances for $\mathrm{Ga}_{2} \mathrm{O}_{3}$ based catalysts in propane dehydrogenation. Nevertheless, according to what I'm informed, the detailed investigations of different supports on the catalytic performances for $\mathrm{Ga}_{2} \mathrm{O}_{3}$ based catalysts are rarely reported, especially with SBA-15 material as support.

The objective of this work is to study the influences of different supports on the state of gallium and the catalytic performances of $\mathrm{Ga}_{2} \mathrm{O}_{3}$-based catalysts for propane dehydrogenation, and further discuss the optimum $\mathrm{Ga}_{2} \mathrm{O}_{3}$ loading content and reaction parameters of $\mathrm{Ga}_{2} \mathrm{O}_{3} / \mathrm{SBA}-15$ catalysts in propane dehydrogenation. A series of different supports (ZSM5 , SBA-15, $\gamma-\mathrm{Al}_{2} \mathrm{O}_{3}$ and $\mathrm{SiO}_{2}$ ) were prepared, and then loaded with $\mathrm{Ga}_{2} \mathrm{O}_{3}$ species by impregnation method. The as-prepared samples were characterized by several state-of-art characterizations. The structure-activity relationships of the catalysts were analyzed and elucidated.

\section{Experimental}

\subsection{Catalyst preparation}

The mesoporous SBA-15 was prepared according to the previous literature. ${ }^{4}$ The triblock copolymer P123 (EO20PO70EO20, $M_{\mathrm{n}}=$ 5800, from Aldrich) was used as the structure-directing agent, and tetraethyl orthosilicate (TEOS) was used as the silica source. In brief, $4 \mathrm{~g}$ of P123 was added in $160 \mathrm{~mL}$ of $2 \mathrm{~mol} \mathrm{~L}^{-1} \mathrm{HCl}$ aqueous solution and stirred for $0.5 \mathrm{~h}$ until fully dissolved, and then $6.4 \mathrm{~g}$ of tetraethyl orthosilicate (TEOS) was slowly dripped to the prepared mixture solution with strong stirring at $40{ }^{\circ} \mathrm{C}$ for $24 \mathrm{~h}$ to get white gel. The resulting gel was subsequently transferred into a Teflon autoclave and held at $100{ }^{\circ} \mathrm{C}$ for $24 \mathrm{~h}$. The obtained sample was filtered and washed using deionized water, and dried in a desiccator overnight. Then, the sample was calcined in air at $550{ }^{\circ} \mathrm{C}$ for $4 \mathrm{~h}$ to remove the structure-directing agent to obtain final SBA-15 powder. Then, the synthesized SBA15 together with other three commercial materials including $\gamma$ $\mathrm{Al}_{2} \mathrm{O}_{3}\left(S_{\text {BET }}: 180 \mathrm{~m}^{2} \mathrm{~g}^{-1}, 80-100 \mathrm{mesh}\right), \mathrm{ZSM}-5$ (Si/Al = 45-80) and $\mathrm{SiO}_{2}$ (particle size $=50 \mathrm{~nm}$ ) were used as supports. The supported $\mathrm{Ga}_{2} \mathrm{O}_{3}$ catalysts were prepared by impregnating the different supports with an aqueous solution of $\mathrm{Ga}\left(\mathrm{NO}_{3}\right)_{3} \cdot x \mathrm{H}_{2} \mathrm{O}$ (Aldrich). Afterward, the prepared samples were aged at room temperature for $4 \mathrm{~h}$, and then the catalysts were dried overnight in air at $100{ }^{\circ} \mathrm{C}$, followed by calcination at $550{ }^{\circ} \mathrm{C}$ for $4 \mathrm{~h}$ in air. The $5 \mathrm{Ga}_{2} \mathrm{O}_{3} / \mathrm{X}$ and $x \mathrm{Ga}_{2} \mathrm{O}_{3} / \mathrm{SBA}-15$ catalysts were got. Unless otherwise specified, as for the $5 \mathrm{Ga}_{2} \mathrm{O}_{3} / \mathrm{X}$ catalysts, the loading of $\mathrm{Ga}_{2} \mathrm{O}_{3}$ was $5 \mathrm{wt} \%$, where $\mathrm{X}$ represents the different support. The prefix $x$ of $x \mathrm{Ga}_{2} \mathrm{O}_{3} / \mathrm{SBA}-15$ samples indicates the different amounts of $\mathrm{Ga}_{2} \mathrm{O}_{3}$ content varying from 1 to $9 \mathrm{wt} \%$.

\subsection{Catalyst characterizations}

2.2.1 XRD. The X-ray diffraction (XRD) patterns of different catalysts were obtained on a Bragg-Brentano diffract meter (Rigaku D/Max-2000) with monochromatic $\mathrm{Cu} \mathrm{K} \alpha$ radiation $(\lambda=$ $1.5418 \AA$ ). The XRD data were collected from 5 to $80^{\circ}$ with a scan speed of $2^{\circ} \min ^{-1}$. The $\mathrm{X}$-ray tube was manipulated at $40 \mathrm{kV}$ and $30 \mathrm{~mA}$.

2.2.2 Low temperature $\mathrm{N}_{2}$ adsorption/desorption. The textural properties of different catalysts were measured by $\mathrm{N}_{2}$ adsorption-desorption at liquid nitrogen temperature using an automatic analyzer (NOVA 4000, Quantachrome, USA). Before adsorption, the catalysts were degassed for $4 \mathrm{~h}$ at $300{ }^{\circ} \mathrm{C}$. The specific surface areas of the samples were calculated using the Brunauer-Emmett-Teller (BET) method. The pore structural data were analyzed by the BJH (Barrett-Joyner-Halenda) method using Halsey equation for multilayer thickness.

2.2.3 FESEM. The morphologies of different catalysts were examined by a field emission scanning electron microscopy (FESEM, HITACHI S-4800) operated at $5.0 \mathrm{kV}$.

2.2.4 TEM. The transmission electron microscopy (TEM) images of different catalysts were analyzed using a JEM-2010 microscope operated at $200 \mathrm{kV}$.

2.2.5 $\mathbf{N H}_{3}$-TPD. The acidity of different catalysts was detected by temperature-programmed desorption of ammonia $\left(\mathrm{NH}_{3}\right.$-TPD). About $0.05 \mathrm{~g}$ of sample was placed into a quartz reactor between two quartz wool plugs. The sample was pretreated at $400{ }^{\circ} \mathrm{C}$ for $1 \mathrm{~h}$ under a dry helium flow $\left(30 \mathrm{~mL} \mathrm{~min}{ }^{-1}\right)$ before being cooled to $120{ }^{\circ} \mathrm{C}$ and saturated with adsorbed gas. A thermal conductivity detector (TCD) was carried out from 120 to $800{ }^{\circ} \mathrm{C}$ with an increasing rate of $10{ }^{\circ} \mathrm{C} \mathrm{min}{ }^{-1}$ to record $\mathrm{NH}_{3}$ TPD profile.

2.2.6 $\mathbf{H}_{2}$-TPR. The temperature-programmed reduction (TPR) for different catalysts was measured in a programmable 
temperature system. Prior to the analysis, the sample $(0.2 \mathrm{~g})$ was treated by dry argon $\left(15 \mathrm{~mL} \mathrm{~min}^{-1}\right)$ at $500{ }^{\circ} \mathrm{C}$ for $1 \mathrm{~h}$ and then the baseline was stabilized at $25{ }^{\circ} \mathrm{C}$ for $60 \mathrm{~min}$. Subsequently, the quartz reactor was heated by a mixed flow of $10 \% \mathrm{H}_{2}$ in $\mathrm{Ar}$ from room temperature to $950{ }^{\circ} \mathrm{C}$ with a heating rate of $10{ }^{\circ} \mathrm{C}$ $\min ^{-1}$. Finally, a TCD cell was employed to monitor and record the consumption profiles of $\mathrm{H}_{2}$.

2.2.7 XPS. The X-ray photoelectron spectra (XPS) of different catalysts were recorded on Perkin-Elmer PHI 5000C ESCA using Al $\mathrm{K} \alpha$ radiation. All the samples were reduced in a hydrogen flow at $580{ }^{\circ} \mathrm{C}$ for $2.5 \mathrm{~h}$. The binding energies (BE) were calibrated using the $\mathrm{C} 1 \mathrm{~s}$ level at $284.8 \mathrm{eV}$ as an internal standard.

2.2.8 TPO. Temperature-programmed oxidation (TPO) experiments for the spent catalysts were conducted in a programmable temperature system. Prior to TPO analysis, the spent catalyst $(0.05 \mathrm{~g})$ was purged in flowing $\mathrm{N}_{2}\left(15 \mathrm{~mL} \mathrm{~min}^{-1}\right)$ at $500{ }^{\circ} \mathrm{C}$ for $1 \mathrm{~h}$. Then, the temperature was lowered to $40{ }^{\circ} \mathrm{C}$ to steady the baseline. Subsequently, the reactor was heated by a mixed gas flow of $10 \% \mathrm{O}_{2}$ in $\mathrm{He}$ from room temperature to $800{ }^{\circ} \mathrm{C}$ at the rate of $10{ }^{\circ} \mathrm{C} \mathrm{min}^{-1}$. Finally, a thermal conductivity detector (TCD) cell was used to determine $\mathrm{CO}_{2}$.

2.2.9 TG. Thermogravimetric analysis was used to determine the coke content on the spent catalysts with a LCT thermogravimetric analyzer (DTG-60H), which was conducted from room temperature to $800{ }^{\circ} \mathrm{C}$ at a rising rate of $20{ }^{\circ} \mathrm{C} \mathrm{min} \mathrm{m}^{-1}$ in a $5 \% \mathrm{O}_{2}-95 \%$ He mixed flow $\left(30 \mathrm{~mL} \mathrm{~min}^{-1}\right)$.

\subsection{Propane dehydrogenation reaction}

The propane dehydrogenation reactions were performed in a quartz fix-bed reactor ( $8 \mathrm{~mm}$ in diameter). The catalyst $(0.2 \mathrm{~g})$ was placed into the center of reactor, and the feed gas including $\mathrm{C}_{3} \mathrm{H}_{8}$ and $\mathrm{Ar}\left(\mathrm{C}_{3} \mathrm{H}_{8} / \mathrm{Ar}\right.$ molar ratio $=1: 19$, WHSV $\left.=0.6 \mathrm{~h}^{-1}\right)$ was fed to the reactor. The propane dehydrogenation reactions were carried out at $620^{\circ} \mathrm{C}$ and atmosphere pressure. A gas chromatography (GC, SP-6890) equipped with a flame ionization detector (FID) and an AT-PLOTPORA-Q capillary column was employed to analyze the gas compositions. The propane conversion and propylene selectivity were calculated by formulas as:

$$
\begin{gathered}
\mathrm{C}_{3} \mathrm{H}_{8} \text { conversion }=\mathrm{C}_{3} \mathrm{H}_{8 \text { in }}-\mathrm{C}_{3} \mathrm{H}_{8 \text { out }} / \mathrm{C}_{3} \mathrm{H}_{8 \text { in }} \\
\mathrm{C}_{3} \mathrm{H}_{6} \text { selectivity }=\mathrm{C}_{3} \mathrm{H}_{6 \text { out }} /\left(\mathrm{C}_{3} \mathrm{H}_{8 \text { in }}-\mathrm{C}_{3} \mathrm{H}_{8 \text { out }}\right)
\end{gathered}
$$

where $\mathrm{C}_{3} \mathrm{H}_{8 \text { in }}$ and $\mathrm{C}_{3} \mathrm{H}_{8 \text { out }}$ are the propane content in feed and exit steams respectively; $\mathrm{C}_{3} \mathrm{H}_{6 \text { out }}$ is the propylene content in exit steam.

\section{Results and discussion}

\subsection{Textural properties}

To evaluate the textural properties of catalysts, the lowtemperature $\mathrm{N}_{2}$-physisorption isotherms were conducted and shown in Fig. 1 (a) and (b). All the $x \mathrm{Ga}_{2} \mathrm{O}_{3} / \mathrm{SBA}-15$ and $5 \mathrm{Ga}_{2} \mathrm{O}_{3} /$ $\mathrm{Al}_{2} \mathrm{O}_{3}$ catalysts exhibit typical type IV adsorption isotherm with a H1-type hysteresis loop as defined by IUPAC, implying the
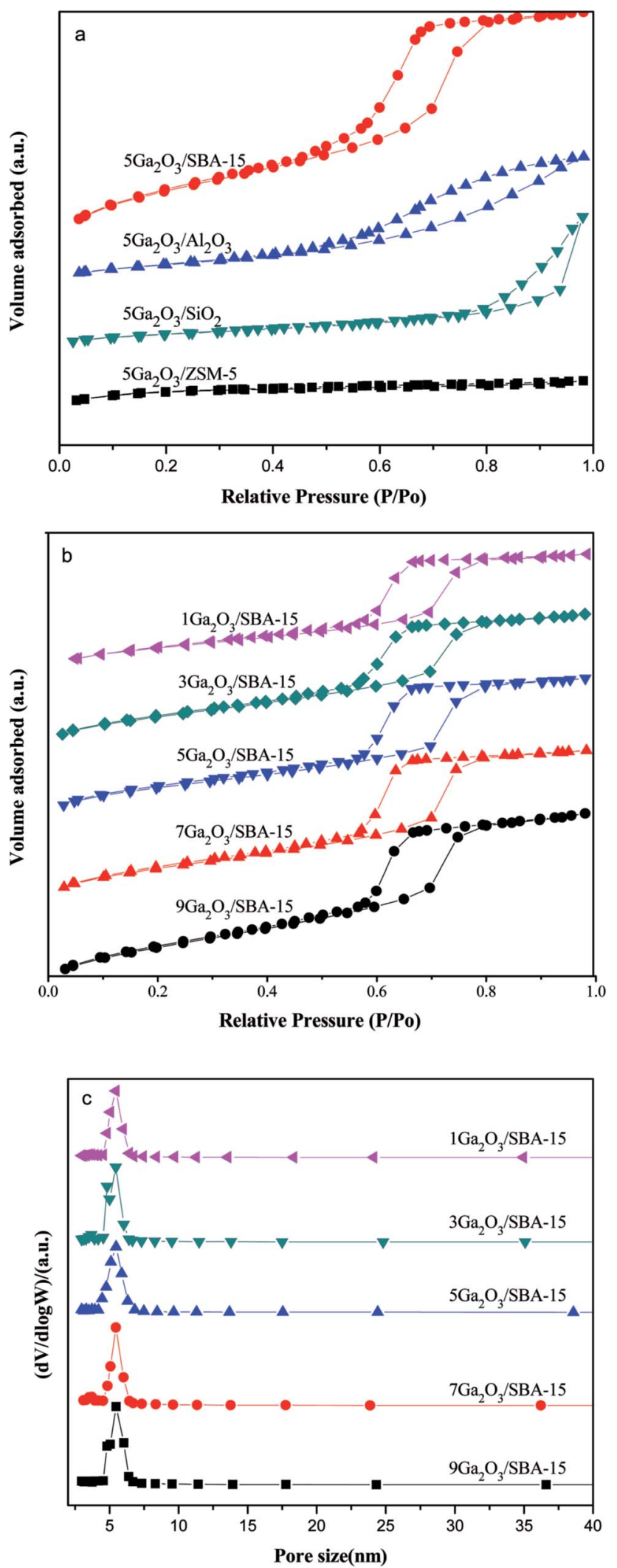

Fig. 1 (a) and (b) Low temperature $\mathrm{N}_{2}$ adsorption-desorption isotherms of $x \mathrm{Ga}_{2} \mathrm{O}_{3} / \mathrm{SBA}-15,5 \mathrm{Ga}_{2} \mathrm{O}_{3} / \mathrm{Al}_{2} \mathrm{O}_{3}, 5 \mathrm{Ga}_{2} \mathrm{O}_{3} / \mathrm{SiO}_{2}, 5 \mathrm{Ga}_{2} \mathrm{O}_{3} /$ ZSM- 5 catalysts and (c) the corresponding pore size distributions of $x \mathrm{Ga}_{2} \mathrm{O}_{3} / \mathrm{SBA}-15$ catalysts. 
presence of mesoporous structure. Moreover, the isotherms of $x \mathrm{Ga}_{2} \mathrm{O}_{3} / \mathrm{SBA}-15$ catalysts show comparatively sharp step with the increase of relative pressure $\left(P / P_{0}\right)$ as compared with that of $5 \mathrm{Ga}_{2} \mathrm{O}_{3} / \mathrm{Al}_{2} \mathrm{O}_{3}$ sample. According to the previous studies, ${ }^{34}$ this is the characteristic of capillary condensation of nitrogen in ordered mesopores. The low-temperature $\mathrm{N}_{2}$-physisorption isotherm for $5 \mathrm{Ga}_{2} \mathrm{O}_{3} / \mathrm{ZSM}-5$ is also illustrated in Fig. 1(a). It shows type I adsorption isotherm with a plateau at higher relative pressure in accordance with the microporous nature of limited mesoporosity of the samples (BDDT classifications ${ }^{31}$ ). Furthermore, the type $\mathrm{H} 3$ (according to IUPAC) hysteresis loop can be noticed for $5 \mathrm{Ga}_{2} \mathrm{O}_{3} / \mathrm{SiO}_{2}$ sample, which often corresponds with the slit-shaped pores. ${ }^{35}$ The textural properties of the different catalysts are listed in Table 1 . As can be seen, the specific surface areas of all the catalysts are mainly determined by the support materials. From Table 1 , the specific surface area $\left(S_{\text {BET }}\right)$ values of different $\mathrm{Ga}_{2} \mathrm{O}_{3}$-based catalysts are in the following sequence: SBA-15 $>\mathrm{ZSM}-5>\mathrm{Al}_{2} \mathrm{O}_{3}>\mathrm{SiO}_{2}$. As regards $x \mathrm{Ga}_{2} \mathrm{O}_{3} /$ SBA-15 catalysts in Fig. 1(b), with the increase of gallium oxide loading from $1 \mathrm{wt} \%$ to $9 \mathrm{wt} \%$, the $S_{\mathrm{BET}}$ and pore volume $\left(V_{\mathrm{p}}\right)$ notably decrease, implying that gallium species might penetrate into the mesoporous channels of SBA-15 and lead the channels to be partially blocked. Moreover, as exhibited in Fig. 2(c), the pore size distributions of $x \mathrm{Ga}_{2} \mathrm{O}_{3} / \mathrm{SBA}-15$ catalysts are measured by the $\mathrm{BJH}$ model according to the desorption branches of the isotherms, and the pore diameter $\left(D_{\mathrm{p}}\right)$ varies little with the increase of $\mathrm{Ga}_{2} \mathrm{O}_{3}$ addition.

\subsection{XRD}

The XRD patterns of the different catalysts are depicted in Fig. 2. Apparently, the characteristic peaks of the corresponding supports are found for all the samples, indicating that the original structure of the support is not destroyed during the catalyst preparation process. In addition, in the wide-angle region (Fig. 2(a)), these materials do not exhibit the characteristic peaks of $\mathrm{Ga}_{2} \mathrm{O}_{3}$ crystalline phases, probably due to their small particle size and/or low concentration below XRD detection limitation. Moreover, the low-angle XRD patterns of $x \mathrm{Ga}_{2} \mathrm{O}_{3} / \mathrm{SBA}-15$ samples are depicted in Fig. 2(b). As can be seen, the unique diffraction planes of (100), (110) and (200) are ascribed to the ordered two-dimensional hexagonal mesoporous structures, and the diffraction peaks of mesoporous structure vary little with the increase of $\mathrm{Ga}_{2} \mathrm{O}_{3}$ content from 1 to $5 \mathrm{wt} \%$. As the $\mathrm{Ga}_{2} \mathrm{O}_{3}$ loading further increases to $7 \mathrm{wt} \%$ and 9

Table 1 Textural properties of the different catalysts

\begin{tabular}{llll}
\hline Samples & $S_{\text {BET }}\left(\mathrm{m}^{2} \mathrm{~g}^{-1}\right)$ & $V_{\mathrm{p}}\left(\mathrm{cm}^{3} \mathrm{~g}^{-1}\right)$ & $D_{\mathrm{p}}(\mathrm{nm})$ \\
\hline $5 \mathrm{Ga}_{2} \mathrm{O}_{3} / \mathrm{ZSM}-5$ & 327 & 0.21 & - \\
$5 \mathrm{Ga}_{2} \mathrm{O}_{3} / \mathrm{Al}_{2} \mathrm{O}_{3}$ & 195 & 0.45 & 5.06 \\
$5 \mathrm{Ga}_{2} \mathrm{O}_{3} / \mathrm{SiO}_{2}$ & 137 & 0.42 & 11.5 \\
$1 \mathrm{Ga}_{2} \mathrm{O}_{3} / \mathrm{SBA}-15$ & 721 & 1.00 & 5.47 \\
$3 \mathrm{Ga}_{2} \mathrm{O}_{3} / \mathrm{SBA}-15$ & 661 & 0.93 & 5.46 \\
$5 \mathrm{Ga}_{2} \mathrm{O}_{3} / \mathrm{SBA}-15$ & 628 & 0.86 & 5.48 \\
$7 \mathrm{Ga}_{2} \mathrm{O}_{3} / \mathrm{SBA}-15$ & 623 & 0.85 & 5.46 \\
$9 \mathrm{Ga}_{2} \mathrm{O}_{3} / \mathrm{SBA}-15$ & 556 & 0.77 & 5.46
\end{tabular}

$\mathrm{wt} \%$, the peak intensity of (100) diffraction plane decreases significantly, and the peak moves to smaller angle location, suggesting that the introduction of overhigh $\mathrm{Ga}_{2} \mathrm{O}_{3}$ weakens the degree of long-range order of SBA-15. ${ }^{36,37}$

\subsection{FESEM and TEM}

The FESEM images of the different catalysts are presented in Fig. 3. As can be seen, the FESEM image of $5 \mathrm{Ga}_{2} \mathrm{O}_{3} / \mathrm{ZSM}-5$ sample reveals highly crystalline zeolites of prismatic structure. In the cases of $x \mathrm{Ga}_{2} \mathrm{O}_{3} / \mathrm{SBA}-15$, they all show bound wormlike feature with a relatively uniform size of about $1 \mu \mathrm{m}$. However, with the increase of $\mathrm{Ga}_{2} \mathrm{O}_{3}$ content from 1 wt $\%$ to 9 $\mathrm{wt} \%$, the long-range worm-like morphology becomes chaos, and the order degree of structure declines. It can be explained that the increase of $\mathrm{Ga}_{2} \mathrm{O}_{3}$ content leads to the collapse of molecular sieve structure.

The ordered porous structures of $5 \mathrm{Ga}_{2} \mathrm{O}_{3} / Z \mathrm{ZSM}-5$ and $x \mathrm{Ga}_{2} \mathrm{O}_{3} /$ SBA-15 samples were further observed by TEM. The images are collected and showed in Fig. 4. From the TEM image of $5 \mathrm{Ga}_{2} \mathrm{O}_{3} /$ ZSM-5 sample, the well-ordered lattice fringes are clearly distinguished in the high-magnification image, which
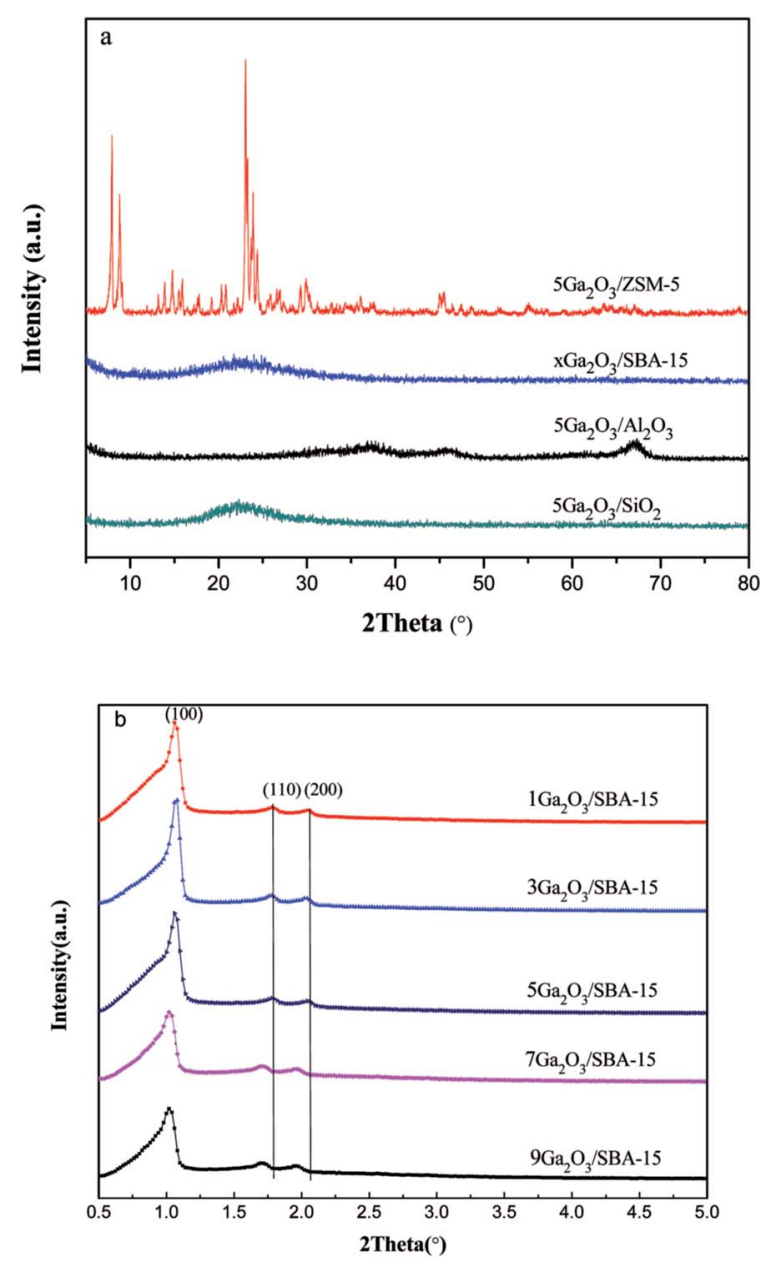

Fig. 2 (a) Wide-angle $X$-ray diffraction patterns of the different catalysts and (b) small-angle $X$-ray diffraction pattern of $x \mathrm{Ga}_{2} \mathrm{O}_{3} / \mathrm{SBA}-15$ catalyst. 
demonstrates the high crystallinity of ZSM-5. As for $x \mathrm{Ga}_{2} \mathrm{O}_{3}$ / SBA-15 samples, the micrographs reveal the presence of wellordered hexagonal arrays of mesoporous channels. However, as loading content increases to $9 \mathrm{wt} \%$, less regular channels are observed from Fig. 4(f). These TEM images are in good agreement with the XRD, BET and SEM results. Furthermore, as indicated by the arrows, the agglomerated gallium species can also be noticed on $7 \mathrm{Ga}_{2} \mathrm{O}_{3} / \mathrm{SBA}-15$ and $9 \mathrm{Ga}_{2} \mathrm{O}_{3} / \mathrm{SBA}-15$ catalysts, which implies that the dispersion of $\mathrm{Ga}$ species is not highly homogeneous under high loading concentration.

\section{4 $\mathrm{NH}_{3}$-TPD}

The acidity of different catalysts was probed by temperatureprogrammed desorption of ammonia method, and the corresponding $\mathrm{NH}_{3}$-TPD curves are displayed in Fig. 5. The semiquantitative analysis is achieved by deconvoluting the peaks using Gaussian curve fitting method. The calculated results containing total acidity and acidity strength distribution are summarized in Table 2 . It is clear that $5 \mathrm{Ga}_{2} \mathrm{O}_{3} / \mathrm{ZSM}-5$ catalyst exhibits two ammonia desorption peaks. The first peak centered (peak I) at $\sim 220{ }^{\circ} \mathrm{C}$ is attributed to the weak acid sites; while the second peak centered (peak II) at $\sim 420{ }^{\circ} \mathrm{C}$ is attributed to the strong acid sites. ${ }^{38}$ Furthermore, the largest strong acid sites also can be observed over $\mathrm{Ga}_{2} \mathrm{O}_{3} / \mathrm{ZSM}-5$ catalyst. From Fig. 5 and Table 2, it can be seen that nearly half of total acidity is ascribed to strong acid sites for $5 \mathrm{Ga}_{2} \mathrm{O}_{3} / \mathrm{ZSM}-5$ catalyst. As regards the
$5 \mathrm{Ga}_{2} \mathrm{O}_{3} / \mathrm{Al}_{2} \mathrm{O}_{3}$ catalyst, it displays three desorption peaks, a broad desorption peak (peak I) centered at $\sim 190{ }^{\circ} \mathrm{C}$ with a shoulder (peak II) at higher temperatures $\sim 270{ }^{\circ} \mathrm{C}$ and a peak (peak III) with a maximal temperature (TM) centered at $\sim 480{ }^{\circ} \mathrm{C}$. It is generally accepted that these three desorption peaks are ascribed to be weak, medium and strong acid sites respectively. ${ }^{39}$ In comparison with $5 \mathrm{Ga}_{2} \mathrm{O}_{3} / \mathrm{ZSM}-5$ and $5 \mathrm{Ga}_{2} \mathrm{O}_{3} /$ $\mathrm{Al}_{2} \mathrm{O}_{3}$ catalysts, the ammonia desorption peaks almost cannot be visible over $x \mathrm{Ga}_{2} \mathrm{O}_{3} / \mathrm{SBA}-15$ and $5 \mathrm{Ga}_{2} \mathrm{O}_{3} / \mathrm{SiO}_{2}$ samples. This phenomenon may be attributed to the inherent nature of pure silicon support. From Table 2, though the $x \mathrm{Ga}_{2} \mathrm{O}_{3} / \mathrm{SBA}-15$ catalysts possess the very weak surface acidity, the acid properties still have some changes with the increase of $\mathrm{Ga}_{2} \mathrm{O}_{3}$ content. The $5 \mathrm{Ga}_{2} \mathrm{O}_{3} / \mathrm{SBA}-15$ and $7 \mathrm{Ga}_{2} \mathrm{O}_{3} / \mathrm{SBA}-15$ samples show relatively high total acidity and weak to medium strong acid sites as compared with those of other three samples, but the change of the amount of strong acid sites is not obvious. The previous studies demonstrated that undesirable side reactions were easily initiated by the strong acid sites of catalysts. ${ }^{40}$ By inference, the undesirable side reactions may easily occur over $5 \mathrm{Ga}_{2} \mathrm{O}_{3} / \mathrm{ZSM}-5$ catalyst.

\section{5 $\quad \mathrm{H}_{2}$-TPR}

To determine the effects of different supports and loading amount on the reduction properties, $\mathrm{H}_{2}$-TPR technique was implemented, and the curves of the corresponding fresh
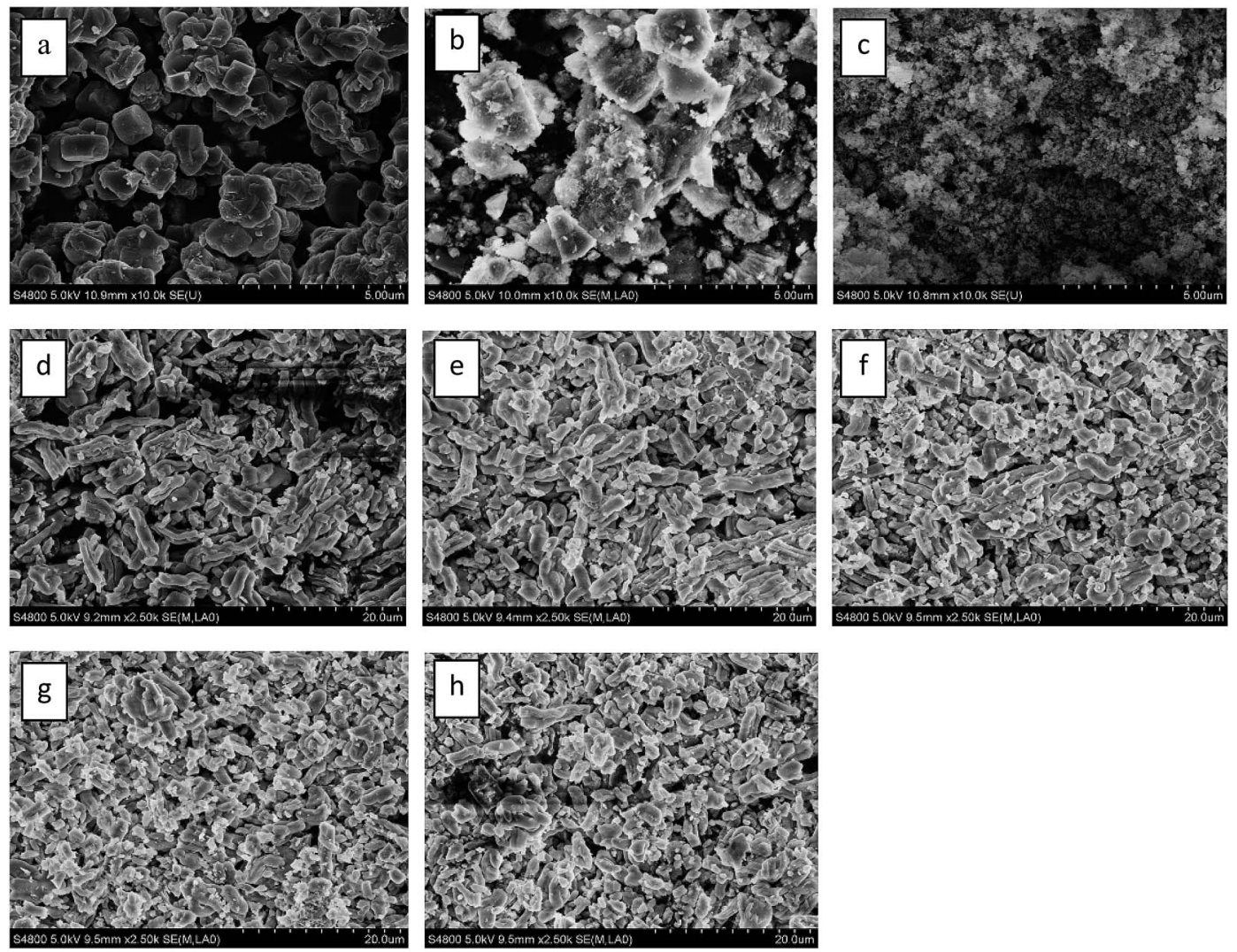

Fig. 3 FESEM images of (a) $5 \mathrm{Ga}_{2} \mathrm{O}_{3} / Z \mathrm{ZSM}-5$; (b) $5 \mathrm{Ga}_{2} \mathrm{O}_{3} / \mathrm{Al}_{2} \mathrm{O}_{3}$; (c) $5 \mathrm{Ga}_{2} \mathrm{O}_{3} / \mathrm{SiO}_{2}$; (d) $1 \mathrm{Ga}_{2} \mathrm{O}_{3} / \mathrm{SBA}-15$; (e) $3 \mathrm{Ga}_{2} \mathrm{O}_{3} / \mathrm{SBA}-15$; (f) $5 \mathrm{Ga}_{2} \mathrm{O}_{3} / \mathrm{SBA}-15$; (g) $7 \mathrm{Ga}_{2} \mathrm{O}_{3} / \mathrm{SBA}-15$; (h) $9 \mathrm{Ga}_{2} \mathrm{O}_{3} / \mathrm{SBA}-15$. 

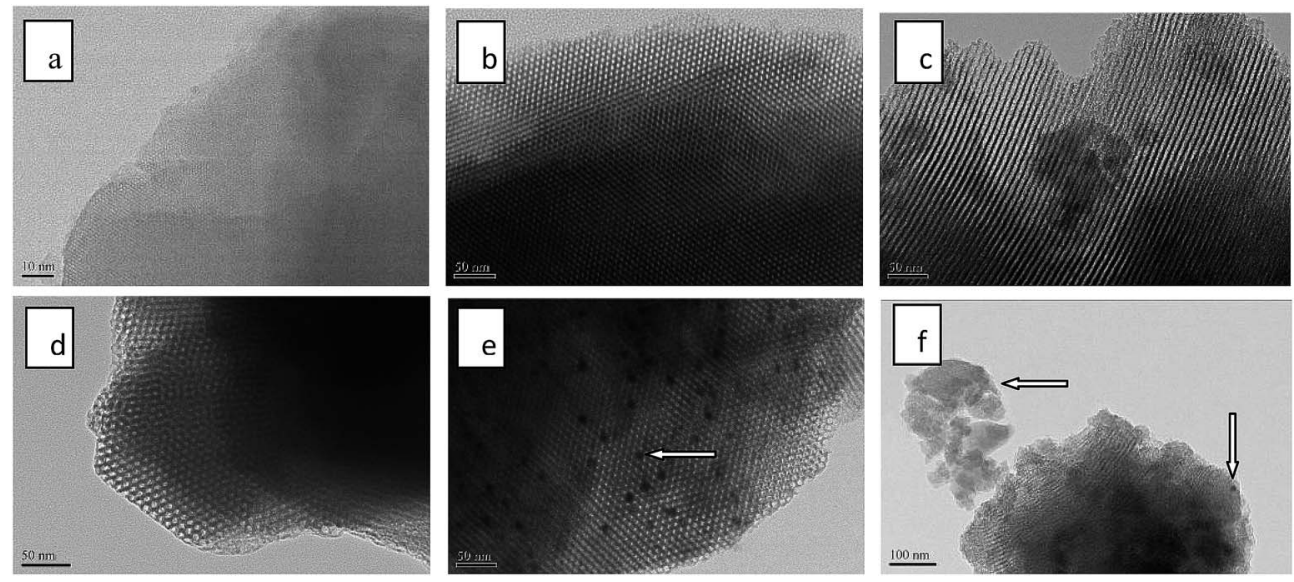

Fig. 4 TEM micrographs of (a) $5 \mathrm{Ga}_{2} \mathrm{O}_{3} / \mathrm{ZSM}-5$; (b) $1 \mathrm{Ga}_{2} \mathrm{O}_{3} / \mathrm{SBA}-15$; (c) $3 \mathrm{Ga}_{2} \mathrm{O}_{3} / \mathrm{SBA}-15$; (d) $5 \mathrm{Ga}_{2} \mathrm{O}_{3} / \mathrm{SBA}-15$; (e) $7 \mathrm{Ga}_{2} \mathrm{O}_{3} / \mathrm{SBA}-15$; (f) $9 \mathrm{Ga} 2 \mathrm{O}_{3} / \mathrm{SBA}-15$.

catalysts are illustrated in Fig. 6(a). The semi-quantitative $\mathrm{H}_{2}$ consumption is summarized in Table 3 , which is obtained by fitting the $\mathrm{H}_{2}$-TPR curves using the Gaussian deconvolution method. It can be seen that all the catalysts present two reduction consumption peaks at about $600{ }^{\circ} \mathrm{C}$ (peak I) and $900{ }^{\circ} \mathrm{C}$ (peak II). As reported previously, ${ }^{26}$ the peak I is ascribed to the reduction of well-dispersed $\mathrm{Ga}$ species, such as micro $\mathrm{Ga}_{2} \mathrm{O}_{3}$ particles and/or $\mathrm{GaO}^{+}$species interacting with the support, and the peak II can be assigned to bulk $\mathrm{Ga}_{2} \mathrm{O}_{3}$ particles and the loosely supported part of $\mathrm{Ga}_{2} \mathrm{O}_{3}$, respectively. In the case of $5 \mathrm{Ga}_{2} \mathrm{O}_{3} / \mathrm{ZSM}-5$, the strongest reduction peak I and the weakest reduction peak II can be observed, implying that the incorporated $\mathrm{Ga}$ species of $5 \mathrm{Ga}_{2} \mathrm{O}_{3} / \mathrm{ZSM}-5$ catalyst are mostly retained as well-dispersed Ga species. The analysis shows that compared with $5 \mathrm{Ga}_{2} \mathrm{O}_{3} / Z \mathrm{ZSM}-5$ catalyst, a weaker reduction peak I and slightly stronger reduction peak II can be observed over the $5 \mathrm{Ga}_{2} \mathrm{O}_{3} / \mathrm{Al}_{2} \mathrm{O}_{3}$ catalyst, suggesting that the amount of welldispersed $\mathrm{Ga}$ species on $5 \mathrm{Ga}_{2} \mathrm{O}_{3} / \mathrm{Al}_{2} \mathrm{O}_{3}$ catalyst is less than that of $5 \mathrm{Ga}_{2} \mathrm{O}_{3} / \mathrm{ZSM}-5$ catalyst. This phenomenon should be highly related to the acidic properties of catalysts. As shown in

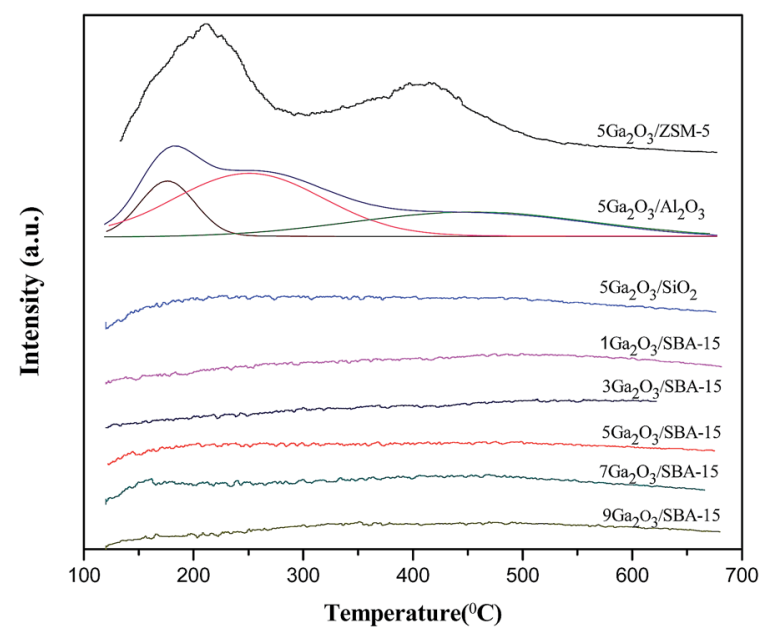

Fig. $5 \mathrm{NH}_{3}$-TPD profiles of the different catalysts.
Table 4 , the ratio of well-dispersed $\mathrm{Ga}$ in $5 \mathrm{Ga}_{2} \mathrm{O}_{3} / \mathrm{ZSM}-5$ to $5 \mathrm{Ga}_{2} \mathrm{O}_{3} / \mathrm{Al}_{2} \mathrm{O}_{3}$ is approximately equal to that of the strong acid peak area in the corresponding samples. This similar phenomenon was also mentioned by Ausavasukhi et al. ${ }^{25} \mathrm{In}$ addition, a small peak at about $690{ }^{\circ} \mathrm{C}$ can be noticed, which should be attributed to the reduction of $\mathrm{OH}$ groups or $\mathrm{Al}$ of alumina support. ${ }^{41}$ On the other hand, Fig. 6 (b) shows the TPR curves of $x \mathrm{Ga}_{2} \mathrm{O}_{3} / \mathrm{SBA}-15$ catalysts. It can be seen that all the samples also display similar two peaks, a small shoulder peak at lower temperature and intensive one at very high temperature even over $950{ }^{\circ} \mathrm{C}$. More specifically, the hydrogen consumption areas of peak II over $x \mathrm{Ga}_{2} \mathrm{O}_{3} / \mathrm{SBA}-15$ catalysts increase as the $\mathrm{Ga}_{2} \mathrm{O}_{3}$ content increases. The $5 \mathrm{Ga}_{2} \mathrm{O}_{3} / \mathrm{SBA}-15$ catalyst exhibits the strongest signal value among all the catalysts, which indicates that the $5 \mathrm{Ga}_{2} \mathrm{O}_{3} / \mathrm{SBA}-15$ sample possesses the largest amount of well-dispersed Ga species. Furthermore, for all the $x \mathrm{Ga}_{2} \mathrm{O}_{3} /$ SBA- 15 catalysts, the peak intensity at about $600{ }^{\circ} \mathrm{C}$ is much weaker than those of $5 \mathrm{Ga}_{2} \mathrm{O}_{3} / \mathrm{ZSM}-5$ and $5 \mathrm{Ga}_{2} \mathrm{O}_{3} / \mathrm{Al}_{2} \mathrm{O}_{3}$ catalysts. This phenomenon can be explained that the low acidity of $x \mathrm{Ga}_{2} \mathrm{O}_{3} / \mathrm{SBA}-15$ catalysts is adverse to the dispersion of Ga species. As for the TPR curve of $5 \mathrm{Ga}_{2} \mathrm{O}_{3} / \mathrm{SiO}_{2}$ sample, two weak reduction peaks for Ga species can be found, which means that the $\mathrm{SiO}_{2}$ support is hard to stabilize small $\mathrm{Ga}_{2} \mathrm{O}_{3}$ particles or $\mathrm{GaO}^{+}$species. It is very unfavorable to the reaction. The similar results were also mentioned in previous reports. ${ }^{42,43}$

Table 2 The semi-quantitative results of $\mathrm{NH}_{3}$-TPD measurements

\begin{tabular}{|c|c|c|c|c|c|c|}
\hline \multirow[b]{2}{*}{ Catalysts } & \multicolumn{3}{|c|}{$\mathrm{TM}\left({ }^{\circ} \mathrm{C}\right)$} & \multirow{2}{*}{$\begin{array}{l}\text { Total area } \\
\text { (a.u.) }\end{array}$} & \multicolumn{2}{|c|}{$\begin{array}{l}\text { Peak area } \\
\text { fraction }(\%)\end{array}$} \\
\hline & I & II & III & & $\mathrm{I}+\mathrm{II}$ & III \\
\hline $5 \mathrm{Ga}_{2} \mathrm{O}_{3} / \mathrm{ZSM}-5$ & 220 & - & 420 & 399 & 53.4 & 46.6 \\
\hline $5 \mathrm{Ga}_{2} \mathrm{O}_{3} / \mathrm{Al}_{2} \mathrm{O}_{3}$ & 190 & 270 & 480 & 403 & 67.3 & 32.7 \\
\hline $5 \mathrm{Ga}_{2} \mathrm{O}_{3} / \mathrm{SiO}_{2}$ & 218 & 314 & 495 & 69.2 & 34.5 & 65.5 \\
\hline $1 \mathrm{Ga}_{2} \mathrm{O}_{3} / \mathrm{SBA}-15$ & 198 & 320 & 502 & 51.4 & 15.8 & 84.2 \\
\hline $3 \mathrm{Ga}_{2} \mathrm{O}_{3} / \mathrm{SBA}-15$ & 206 & 316 & 513 & 48.6 & 13.4 & 86.6 \\
\hline $5 \mathrm{Ga}_{2} \mathrm{O}_{3} / \mathrm{SBA}-15$ & 200 & 301 & 460 & 60.8 & 27.8 & 72.2 \\
\hline $7 \mathrm{Ga}_{2} \mathrm{O}_{3} / \mathrm{SBA}-15$ & 180 & 318 & 455 & 53.2 & 23.2 & 76.8 \\
\hline $9 \mathrm{Ga}_{2} \mathrm{O}_{3} / \mathrm{SBA}-15$ & 179 & 301 & 486 & 49.3 & 18.3 & 81.7 \\
\hline
\end{tabular}



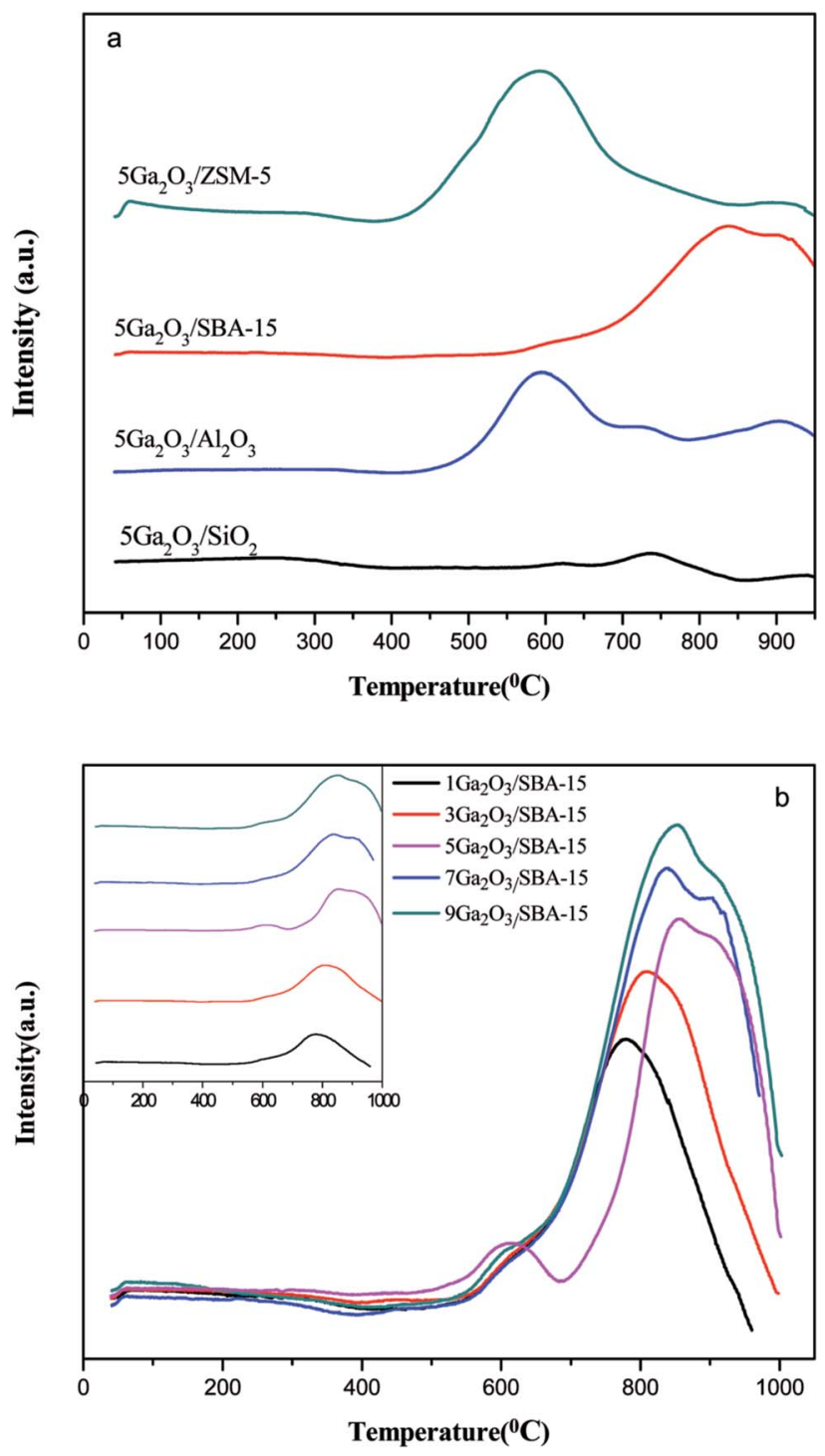

Fig. $6 \mathrm{H}_{2}$-TPR profiles of the different catalysts.

\subsection{XPS}

To further elucidate the chemical state of Ga species, XPS analyses were measured. The XPS spectra and semi-quantitative results of various catalysts are shown in Fig. 7 and Table 5 respectively. As can be seen in Fig. 7, $5 \mathrm{Ga}_{2} \mathrm{O}_{3} / \mathrm{ZSM}-5$ and $5 \mathrm{Ga}_{2} \mathrm{O}_{3} / \mathrm{Al}_{2} \mathrm{O}_{3}$ catalysts present three peaks at $\sim 25 \mathrm{eV}$ (peak I), $\sim 21 \mathrm{eV}$ (peak II) and $\sim 19.8 \mathrm{eV}$ (peak III) similar to the previous literatures. ${ }^{16,44,45}$ The high binding energy $(\sim 25 \mathrm{eV})$ is ascribed to O2s band; the binding energy $(\sim 21 \mathrm{eV})$ is assigned to Ga3d band, and the low energy peak at $\sim 19.8 \mathrm{eV}$ is attributed to $\mathrm{Ga}^{\delta+}$ species $(\delta<2) .^{45}$ From Table 5 , the percentages of $\mathrm{Ga}^{\delta+}$ species $(\delta$ $<2$ ) for $5 \mathrm{Ga}_{2} \mathrm{O}_{3} / \mathrm{ZSM}-5$ and $5 \mathrm{Ga}_{2} \mathrm{O}_{3} / \mathrm{Al}_{2} \mathrm{O}_{3}$ catalysts are about $62 \%$ and $11 \%$ respectively, implying that partial $\mathrm{Ga}_{2} \mathrm{O}_{3}$ is reduced on these two supports during the catalyst preparation process. The similar viewpoint was also reported in the previous literature. ${ }^{46}$ As for $x \mathrm{Ga}_{2} \mathrm{O}_{3} / \mathrm{SBA}-15$ and $5 \mathrm{Ga}_{2} \mathrm{O}_{3} / \mathrm{SiO}_{2}$ catalysts, there are two deconvoluted peaks (peak I and peak II). The fraction of gallium in the oxidized state for $x \mathrm{Ga}_{2} \mathrm{O}_{3} / \mathrm{SBA}-15$
Table 3 The semi-quantitative $\mathrm{H}_{2}$-TPR results for the different catalysts

\begin{tabular}{llll}
\hline Catalysts & $\begin{array}{l}\text { Total area } \\
\left(\text { a.u. }\left(\times 10^{4}\right)\right.\end{array}$ & $\begin{array}{l}\text { Peak I area } \\
(\text { a.u. })\left(\times 10^{4}\right)\end{array}$ & $\begin{array}{l}\text { Peak II area } \\
(\text { a.u. })\left(\times 10^{4}\right)\end{array}$ \\
\hline $5 \mathrm{Ga}_{2} \mathrm{O}_{3} / \mathrm{ZSM}-5$ & 1.60 & 1.38 & 0.22 \\
$5 \mathrm{Ga}_{2} \mathrm{O}_{3} / \mathrm{SBA}^{4}-15$ & 1.34 & 0.05 & 1.29 \\
$5 \mathrm{Ga}_{2} \mathrm{O}_{3} / \mathrm{Al}_{2} \mathrm{O}_{3}$ & 1.41 & 0.99 & 0.42 \\
$5 \mathrm{Ga}_{2} \mathrm{O}_{3} / \mathrm{SiO}_{2}$ & 0.05 & 0.01 & 0.04
\end{tabular}

catalyst increases with the increase of $\mathrm{Ga}_{2} \mathrm{O}_{3}$ content from 1 to $9 \mathrm{wt} \%$. Moreover, it can be seen from Table 5 that the Ga3d banding energy of the gallium species in the $\mathrm{Ga}_{2} \mathrm{O}_{3} / \mathrm{SiO}_{2}$ is reduced by 0.5 as compared with those in the other three samples. It is remarkable that the Ga3d banding energy of the gallium species in pure $\beta-\mathrm{Ga}_{2} \mathrm{O}_{3}$ is the same as that in $5 \mathrm{Ga}_{2} \mathrm{O}_{3}$ / $\mathrm{SiO}_{2}$ catalyst, ${ }^{44}$ indicating that using $\mathrm{ZSM}-5, \mathrm{Al}_{2} \mathrm{O}_{3}$ and SBA-15 supports can strengthen the interaction between $\mathrm{Ga}$ species and support. The similar conclusion was also reported by $\mathrm{Xu}$ et $a l .{ }^{18}$ These results imply that the different supports can play a significant role in determining the chemical state of $\mathrm{Ga}$ species.

\subsection{Catalytic performances}

3.7.1 Effect of different supports. The catalysts with different supports were subjected to the propane dehydrogenation reaction for $30 \mathrm{~h}$. The propane conversion and propylene selectivity are displayed in Fig. 8. As can be seen, the initial conversions of propane for different catalysts decrease in the following order: $5 \mathrm{Ga}_{2} \mathrm{O}_{3} / \mathrm{ZSM}-5>5 \mathrm{Ga}_{2} \mathrm{O}_{3} / \mathrm{Al}_{2} \mathrm{O}_{3}>5 \mathrm{Ga}_{2} \mathrm{O}_{3} / \mathrm{SBA}-15$ $>5 \mathrm{Ga}_{2} \mathrm{O}_{3} / \mathrm{SiO}_{2}$. The $5 \mathrm{Ga}_{2} \mathrm{O}_{3} / \mathrm{ZSM}-5$ catalyst shows the highest initial propane conversion (78.1\%), which is much higher than those of the other samples. However, the worst stability of $5 \mathrm{Ga}_{2} \mathrm{O}_{3} / \mathrm{ZSM}-5$ catalyst is found among all the samples. The final propane conversion is only $11.5 \%$. As regards the $5 \mathrm{Ga}_{2} \mathrm{O}_{3}$ / SBA-15 sample, although the initial conversion of propane is $29.7 \%$, it exhibits the highest catalytic stability. The final propane conversion still attains $21.4 \%$ after $30 \mathrm{~h}$ of propane dehydrogenation reaction. When the $\mathrm{Al}_{2} \mathrm{O}_{3}$ is chosen as the support, the relatively high initial propane conversion $(46.0 \%)$ over $5 \mathrm{Ga}_{2} \mathrm{O}_{3} / \mathrm{Al}_{2} \mathrm{O}_{3}$ can be obtained, but the quick deactivation of this sample is also observed, and the final conversion value is only $5.3 \%$. For the $5 \mathrm{Ga}_{2} \mathrm{O}_{3} / \mathrm{SiO}_{2}$ catalyst, a low and stable propane conversion (around 5.5\%) can be observed. The TOF values of different catalysts at $20 \mathrm{~h}$ are calculated and included

Table 4 The relationship between the reduction properties and the strong acid sites on the different supports

\begin{tabular}{|c|c|c|c|}
\hline & $5 \mathrm{Ga}_{2} \mathrm{O}_{3} / \mathrm{ZSM}-5$ & $5 \mathrm{Ga}_{2} \mathrm{O}_{3} / \mathrm{Al}_{2} \mathrm{O}_{3}$ & Area ratio \\
\hline $\begin{array}{l}\mathrm{H}_{2}-\mathrm{TPR} \text { peak I area } \\
\text { (a.u.) }\end{array}$ & 1.38 & 0.99 & 1.39 \\
\hline $\begin{array}{l}\mathrm{NH}_{3} \text {-TPD peak III area } \\
\text { (a.u.) }\end{array}$ & 185.93 & 131.78 & 1.41 \\
\hline
\end{tabular}



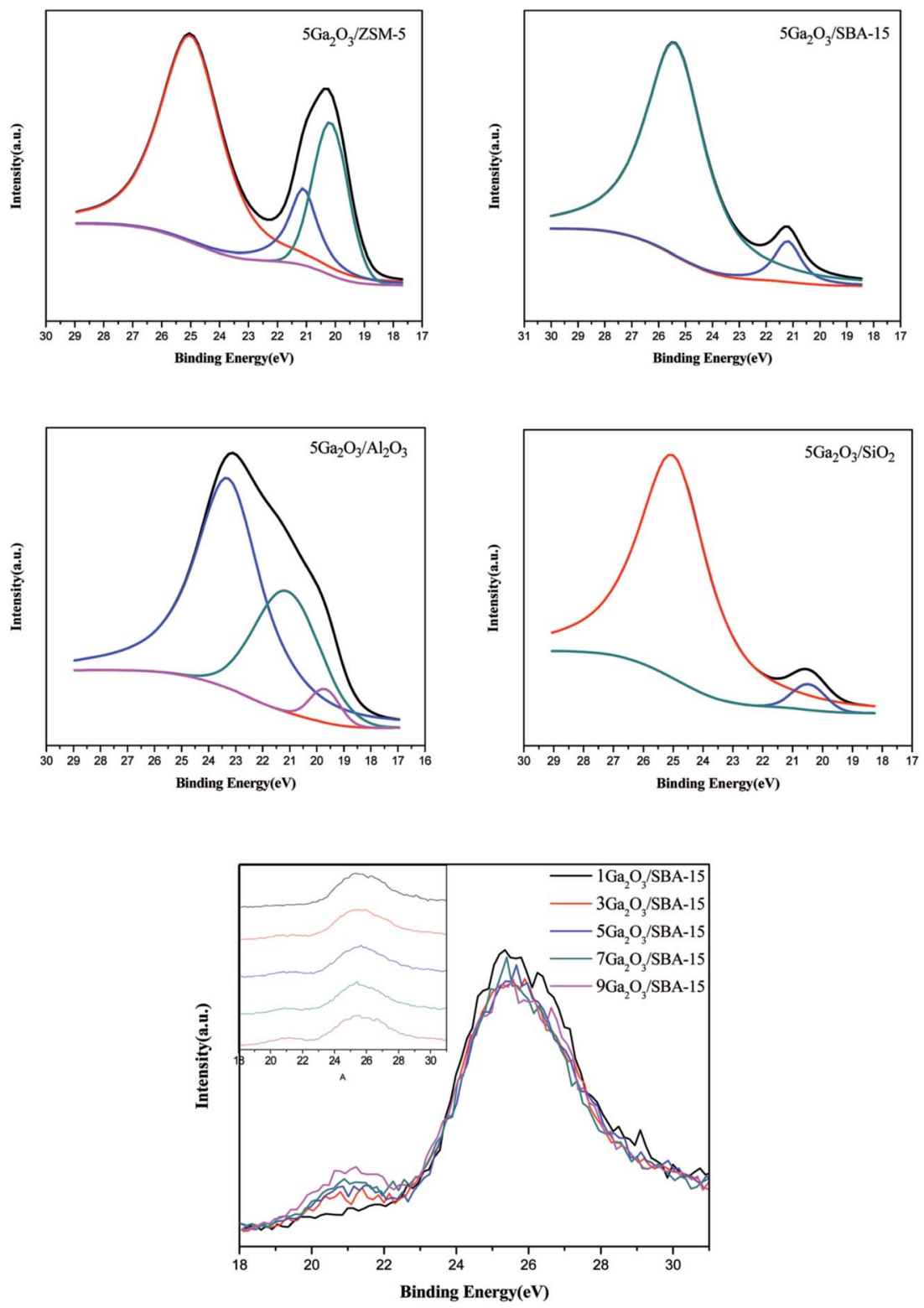

Fig. 7 Ga3d XPS spectra of the different catalysts.

in Table 6. It is remarkable that the TOF values show the similar variation regularity to that of propane conversion over the corresponding catalysts. The highest TOF value can be found over $5 \mathrm{Ga}_{2} \mathrm{O}_{3} /$ SBA-15 catalyst, indicating that it displays the high dehydrogenation efficiency of Ga species.

From Fig. 8, it can be seen that the propylene selectivity exhibits an apparent rise of for $5 \mathrm{Ga}_{2} \mathrm{O}_{3} / \mathrm{ZSM}-5$ catalyst in the initial several hours and then gradually stabilizes at around $89 \%$ after $8 \mathrm{~h}$ reaction. The $5 \mathrm{Ga}_{2} \mathrm{O}_{3} / \mathrm{Al}_{2} \mathrm{O}_{3}$ catalyst presents the highest initial propylene selectivity, and slightly decreases from $95.8 \%$ to $85.1 \%$ after $30 \mathrm{~h}$ reaction. The propylene selectivity for $5 \mathrm{Ga}_{2} \mathrm{O}_{3} / \mathrm{SBA}-15$ catalyst attains about $92.0 \%$ and varies little in the whole $30 \mathrm{~h}$ reaction period. As for the $5 \mathrm{Ga}_{2} \mathrm{O}_{3} / \mathrm{SiO}_{2}$ sample, a relatively low propylene selectivity of around $86 \%$ is observed.

The variation of the catalytic performances can be explained as following. In general, for $\mathrm{Ga}_{2} \mathrm{O}_{3}$-supported catalysts, there are three kinds of active centers in the fresh catalysts: welldispersed $\mathrm{Ga}$ species, $\mathrm{GaO}^{+}$and bulk $\mathrm{Ga}_{2} \mathrm{O}_{3} \cdot{ }^{25,47}$ The welldispersed $\mathrm{Ga}$ species and $\mathrm{GaO}^{+}$usually have higher dehydrogenation activity as compared with bulk $\mathrm{Ga}_{2} \mathrm{O}_{3} \cdot{ }^{25}$ It can be seen from the $\mathrm{H}_{2}$-TPR curves in Fig. 6 that the initial catalytic activities of different catalysts are in good agreement with the amount of well-dispersed Ga species of the corresponding catalysts. Furthermore, the TEM images also certify the existence of bulk $\mathrm{Ga}_{2} \mathrm{O}_{3}$ in $7 \mathrm{Ga}_{2} \mathrm{O}_{3} / \mathrm{SBA}-15$ and $9 \mathrm{Ga}_{2} \mathrm{O}_{3} / \mathrm{SBA}-15$ samples. Secondly, the researchers reported that the reduced gallium ions $\left(\mathrm{Ga}^{\delta+}\right.$ cations, $\left.\delta<2\right)$ were considered to be a reason for the high activity, and monovalent Ga was regarded as the second most active species. ${ }^{25,47,48}$ As shown in Fig. 7 and Table 5, the content of the reduced gallium species on $5 \mathrm{Ga}_{2} \mathrm{O}_{3} / \mathrm{ZSM}-5$ catalyst and $5 \mathrm{Ga}_{2} \mathrm{O}_{3} / \mathrm{Al}_{2} \mathrm{O}_{3}$ catalyst are $62 \%$ and $11 \%$ respectively. Nevertheless, the reduced gallium species cannot be 
Table 5 The semi-quantitative XPS results for the different catalysts

\begin{tabular}{llrr}
\hline Catalysts & $\begin{array}{l}\text { Ga3d binding } \\
\text { energy }(\mathrm{eV})\end{array}$ & $\mathrm{Ga}^{3+}(\%)$ & $\mathrm{Ga}^{\delta+a}(\%)$ \\
\hline $5 \mathrm{Ga}_{2} \mathrm{O}_{3} / \mathrm{ZSM}-5$ & $21.0 / 19.8$ & 38 & 62 \\
$x \mathrm{Ga}_{2} \mathrm{O}_{3} / \mathrm{SBA}-15$ & 21.0 & 100 & 0 \\
$5 \mathrm{Ga}_{2} \mathrm{O}_{3} / \mathrm{Al}_{2} \mathrm{O}_{3}$ & $21.0 / 19.8$ & 89 & 11 \\
$5 \mathrm{Ga}_{2} \mathrm{O}_{3} / \mathrm{SiO}_{2}$ & 20.5 & 100 & 0 \\
${ }^{a} \delta<2$. & & \\
& & &
\end{tabular}

found over the other two pure silica supported catalysts. In this sense, this is another reasonable explanation for the much better catalytic performance of $5 \mathrm{Ga}_{2} \mathrm{O}_{3} / \mathrm{ZSM}-5$ than the other three catalysts. Thirdly, as shown in Table 5, the weak interaction between $\mathrm{Ga}$ species and $\mathrm{SiO}_{2}$ support is found for $5 \mathrm{Ga}_{2} \mathrm{O}_{3} /$ $\mathrm{SiO}_{2}$ sample, but the other three catalysts exhibit the strong interactions between Ga species and the supports. This may be the reason why $5 \mathrm{Ga}_{2} \mathrm{O}_{3} / \mathrm{SiO}_{2}$ catalyst possesses the lowest catalytic activity. Finally, according to the textural parameters in Fig. 1 and Table 1, the relatively high surface area and unique structure of ZSM-5 support may be responsible for the relatively high catalytic activity of $5 \mathrm{Ga}_{2} \mathrm{O}_{3} / \mathrm{ZSM}-5$ catalyst.

As for the changes of propylene selectivity, it is well-known that the strong acid sites generally promote the deep dehydrogenation due to isomerization and coking reactions on the surfaces of catalysts. Aromatization of propylene would also take place on the Brønsted acid sites of supports. All these factors will lower propylene selectivity. ${ }^{49}$ Moreover, not only the surface acidic properties of support but also the active components can give rise to the variation of propylene selectivity. The previous study has proved that the dihydrogen molecule is dissociatively adsorbed on gallium oxide on the catalyst surface, which may cause the occurrence of hydrogenolysis reaction. ${ }^{50}$ With regards to $5 \mathrm{Ga}_{2} \mathrm{O}_{3}$ / ZSM-5 sample, the lowest selectivity in the initial hours must be related to the strong acidity sites and well-dispersed Ga species, which results in more side reactions (Fig. 9). Meantime, there also

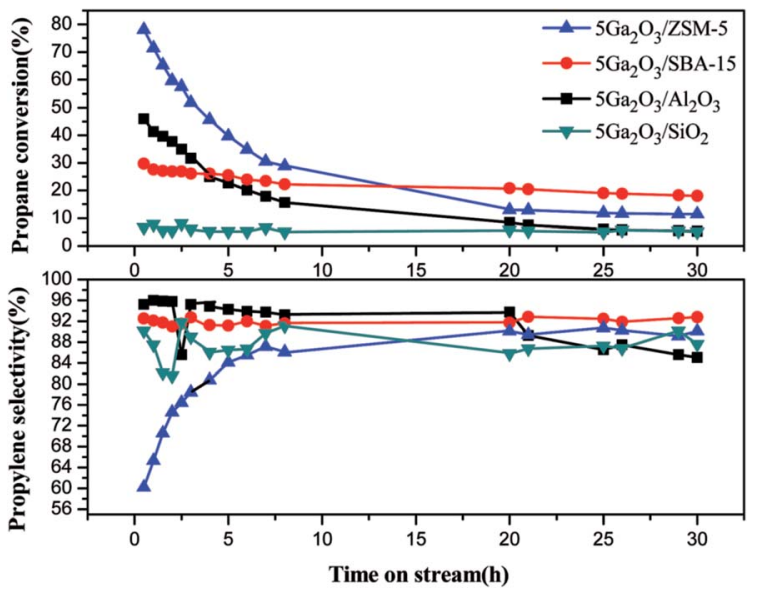

Fig. 8 Propane conversion and propylene selectivity of the different catalysts as a function of time (reaction conditions: $T=620{ }^{\circ} \mathrm{C}$; $\mathrm{C}_{3} \mathrm{H}_{8}: \operatorname{Ar}($ molar ratio $)=1: 19 ; \mathrm{WHSV}=0.6 \mathrm{~h}^{-1} ; m_{\text {cat. }}=0.2 \mathrm{~g}$. exist the relatively high selectivities to methane and ethane (Fig. 9), implying the occurrence of hydrogenolysis reaction, and the following increased selectivity should be due to the cover of acid sites by coke deposits. For the $5 \mathrm{Ga}_{2} \mathrm{O}_{3} / \mathrm{Al}_{2} \mathrm{O}_{3}$ catalyst, the $\mathrm{NH}_{3}$-TPD results (Fig. 5) show that the strong acid sites are relatively suitable, and thus the undesired side reactions can be suppressed. The $5 \mathrm{Ga}_{2} \mathrm{O}_{3} / \mathrm{SBA}-15$ and $5 \mathrm{Ga}_{2} \mathrm{O}_{3} / \mathrm{SiO}_{2}$ samples possess the relatively high propylene selectivity values among all the samples, which are consistent with the extremely weak acidity.

3.7.2 Effect of $\mathrm{Ga}_{2} \mathrm{O}_{3}$ content. The catalytic performances over $x \mathrm{Ga}_{2} \mathrm{O}_{3} / \mathrm{SBA}-15$ catalysts with different $\mathrm{Ga}_{2} \mathrm{O}_{3}$ content are illustrated in Fig. 10. It can be observed that $5 \mathrm{Ga}_{2} \mathrm{O}_{3} / \mathrm{SBA}-15$ sample shows the highest conversion, selectivity and catalytic stability, which has the initial propane conversion and final one of $31.7 \%$ and $30.3 \%$. However, the higher or lower $\mathrm{Ga}_{2} \mathrm{O}_{3}$ loading amount both leads to a decline of initial propane conversion. $1 \mathrm{Ga}_{2} \mathrm{O}_{3} / \mathrm{SBA}-15$ sample exhibits the lowest catalytic activity among all the catalysts. The TOF values of $x \mathrm{Ga}_{2} \mathrm{O}_{3} / \mathrm{SBA}-$ 15 are also shown in Table 6 . It can be seen that $1 \mathrm{Ga}_{2} \mathrm{O}_{3} / \mathrm{SBA}-15$ sample has the highest TOF value, which should be ascribed to the high $\mathrm{Ga}$ species dispersion under the minimum $\mathrm{Ga}_{2} \mathrm{O}_{3}$ loading. As for the other samples, the TOF values first increase, and then decrease with the increase of the amount of gallium oxide, and the $5 \mathrm{Ga}_{2} \mathrm{O}_{3} / \mathrm{SBA}-15$ sample possesses the second highest TOF value. This phenomenon can be probably attributed to the formation of bulk $\mathrm{Ga}_{2} \mathrm{O}_{3}$, which leads to the decline of dehydrogenation efficiency of gallium oxide.

From Fig. 10, $5 \mathrm{Ga}_{2} \mathrm{O}_{3} / \mathrm{SBA}-15$ catalyst presents the highest propylene selectivity among all the samples. $1 \mathrm{Ga}_{2} \mathrm{O}_{3} / \mathrm{SBA}-15$ and $9 \mathrm{Ga}_{2} \mathrm{O}_{3} / \mathrm{SBA}-15$ catalysts show the relatively lower propylene selectivities. Also, it is found that the propylene selectivity has the similar variation trend to propane conversion with regard to the $\mathrm{Ga}_{2} \mathrm{O}_{3}$ content for $x \mathrm{Ga}_{2} \mathrm{O}_{3} / \mathrm{SBA}-15$ catalysts.

The catalytic performances over the synthesized catalysts with different loadings can be explained as following. According

Table 6 Amounts of coke on the spent different supported and $x \mathrm{Ga}_{2} \mathrm{O}_{3} / \mathrm{SBA}-15$ catalysts for propane dehydrogenation after $30 \mathrm{~h}$ and $2 \mathrm{~h}$ reaction respectively, and TOF values of the different catalysts ${ }^{a}$

\begin{tabular}{lll}
\hline Samples & Coke amount & TOF $\left(\mathrm{s}^{-1}\right)\left(\times 10^{-2}\right)$ \\
\hline $5 \mathrm{Ga}_{2} \mathrm{O}_{3} / \mathrm{ZSM}-5^{c}$ & 12.6 & 1.81 \\
$5 \mathrm{Ga}_{2} \mathrm{O}_{3} / \mathrm{SBA}^{c} 5^{c}$ & 4.55 & 2.91 \\
$5 \mathrm{Ga}_{2} \mathrm{O}_{3} / \mathrm{Al}_{2} \mathrm{O}_{3}{ }^{c}$ & 2.86 & 1.16 \\
$5 \mathrm{Ga}_{2} \mathrm{O}_{3} / \mathrm{SiO}_{2}{ }^{c}$ & 0.96 & 0.80 \\
$1 \mathrm{Ga}_{2} \mathrm{O}_{3} / \mathrm{SBA}-15^{d}$ & 3.97 & 6.92 \\
$3 \mathrm{Ga}_{2} \mathrm{O}_{3} / \mathrm{SBA}-15^{d}$ & 5.85 & 3.72 \\
$5 \mathrm{Ga}_{2} \mathrm{O}_{3} / \mathrm{SBA}-15^{d}$ & 3.11 & 4.20 \\
$7 \mathrm{Ga}_{2} \mathrm{O}_{3} / \mathrm{SBA}-15^{d}$ & 6.32 & 2.08 \\
$9 \mathrm{Ga}_{2} \mathrm{O}_{3} / \mathrm{SBA}-15^{d}$ & 6.52 & 1.64 \\
$\mathrm{SBA}-15$ & 0.82 & -
\end{tabular}

${ }^{a}$ Note: the coke on the SBA- 15 and the $\mathrm{Ga}_{2} \mathrm{O}_{3}$ catalysts supported on various supports was measured after $30 \mathrm{~h}$ of propane dehydrogenation reaction; the coke on the $x \mathrm{Ga}_{2} \mathrm{O}_{3} / \mathrm{SBA}-15$ was measured after $2 \mathrm{~h}$ of propane dehydrogenation reaction. ${ }^{b}$ Experimental value calculated from thermogravimetric (TG) analysis. ${ }^{c} \mathrm{C}_{3} \mathrm{H}_{8}$ turn frequency (TOF) in the $20 \mathrm{~h}$ reaction. ${ }^{d} \mathrm{C}_{3} \mathrm{H}_{8}$ turn frequency (TOF) in the $2 \mathrm{~h}$ reaction. 


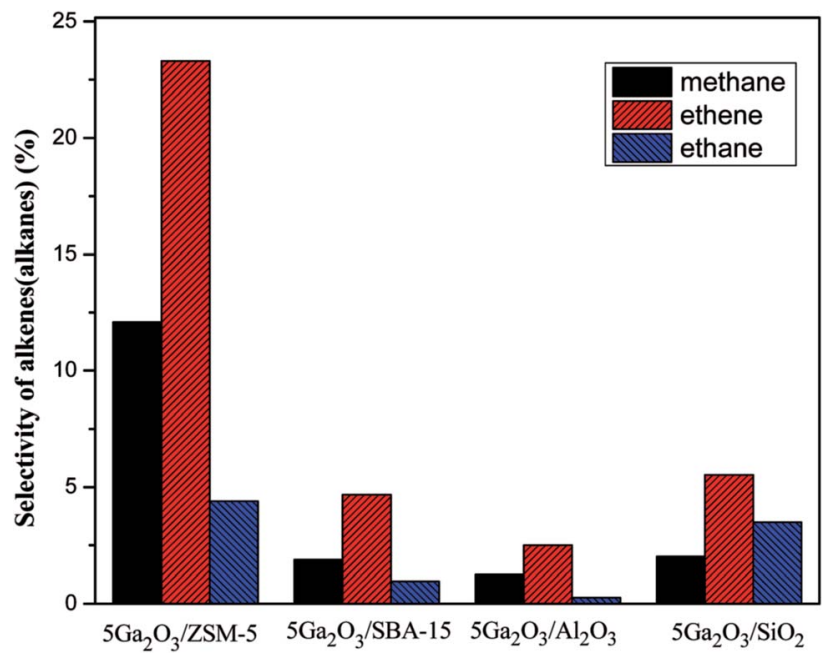

Fig. 9 Selectivities to alkanes (alkenes) over the different catalysts in the initial 30 min reaction: (reaction conditions: $T=620{ }^{\circ} \mathrm{C}_{;} \mathrm{C}_{3} \mathrm{H}_{8}: \mathrm{Ar}$ $($ molar ratio $)=1: 19 ;$ WHSV $\left.=0.6 \mathrm{~h}^{-1} ; m_{\text {cat. }}=0.2 \mathrm{~g}\right)$.

to XRD, BET, SEM and TEM results, the high $\mathrm{Ga}_{2} \mathrm{O}_{3}$ content can block the pores of SBA-15, destroy the structural integrity of SBA-15 and lead to the formation of bulk Ga species on the support. The $\mathrm{H}_{2}$-TPR curves in Fig. 6(b) also verify that more well-dispersed $\mathrm{Ga}$ species exist on $5 \mathrm{Ga}_{2} \mathrm{O}_{3} / \mathrm{SBA}-15$ sample, which is in coincidence with the best catalytic performance. Furthermore, as shown in Table 2, the catalytic performances of $x \mathrm{Ga}_{2} \mathrm{O}_{3} / \mathrm{SBA}-15$ catalysts are closely related to the variation of the total acid of the catalysts with respect to $\mathrm{Ga}_{2} \mathrm{O}_{3}$ content. It is notable that the strong acid sites of $x \mathrm{Ga}_{2} \mathrm{O}_{3} / \mathrm{SBA}-15$ catalysts almost vary little with the increase of $\mathrm{Ga}_{2} \mathrm{O}_{3}$ content, and all the catalysts have the similar amounts of well-dispersed Ga species, implying that the influence of the amount of well-dispersed $\mathrm{Ga}$ species is mostly related to the acidity rather than the loading content of $\mathrm{Ga}_{2} \mathrm{O}_{3}$. When $\mathrm{Ga}$ content increases, the Ga species

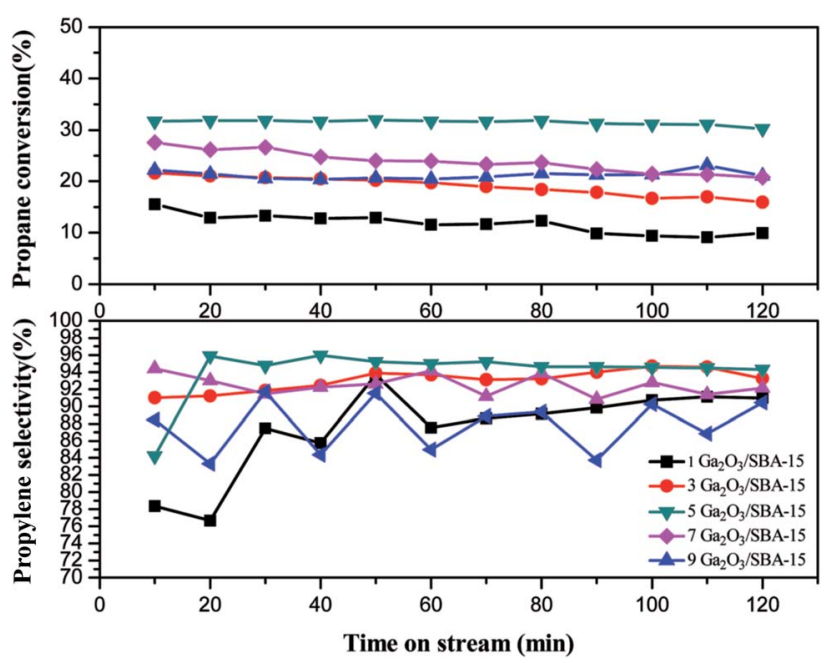

Fig. 10 The effect of $\mathrm{Ga}_{2} \mathrm{O}_{3}$ content of the catalysts on the catalytic performance in propane dehydrogenation (reaction conditions: $T=$ $620^{\circ} \mathrm{C} ; \mathrm{C}_{3} \mathrm{H}_{8}: \operatorname{Ar}($ molar ratio $)=1: 19 ; \mathrm{WHSV}=0.6 \mathrm{~h}^{-1} ; m_{\text {cat. }}=0.2 \mathrm{~g}$ ).

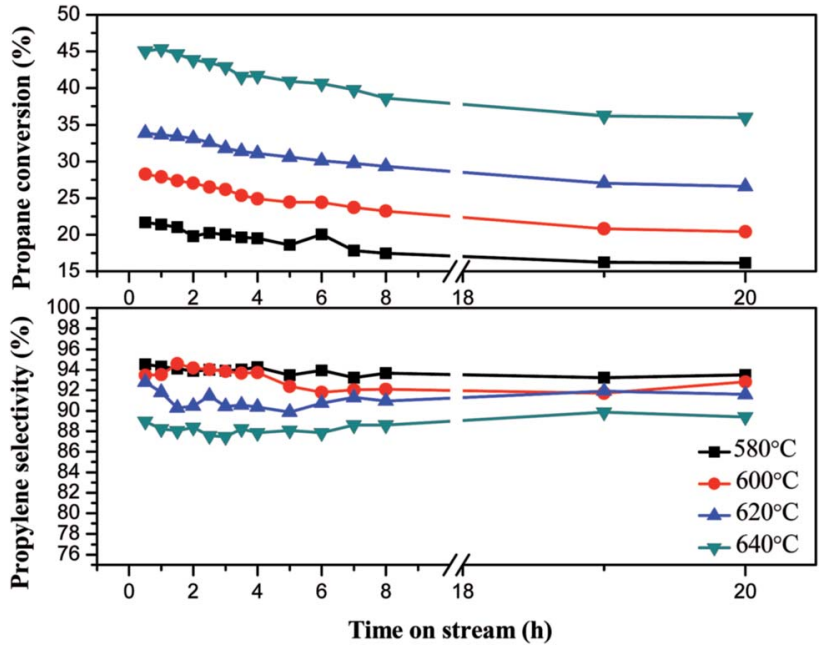

Fig. 11 The effect of reaction temperature on the performance of $5 \mathrm{Ga}_{2} \mathrm{O}_{3} / \mathrm{SBA}-15$ catalyst in propane dehydrogenation.

begin to enrich in the form of large $\mathrm{Ga}_{2} \mathrm{O}_{3}$ clusters rather than well-dispersed species. Ausavasukhi et al. ${ }^{43}$ also reported a similar conclusion.

3.7.3 Effect of reaction temperature. Fig. 11 shows the effect of reaction temperature on the performance of $5 \mathrm{Ga}_{2} \mathrm{O}_{3}$ / SBA-15 catalyst in propane dehydrogenation. The initial propane conversions of $21.7 \%, 28.3 \%, 33.8 \%$ and $45.0 \%$ are obtained at 580,600, 620 and $640{ }^{\circ} \mathrm{C}$ respectively, and they decrease to $16.1 \%, 20.4 \%, 26.6 \%$ and $36.0 \%$ after $20 \mathrm{~h}$ reaction. The initial propylene selectivities are $94.5 \%, 93.5 \%, 92.8 \%$ and $90 \%$ at $580,600,620$ and $640{ }^{\circ} \mathrm{C}$ respectively. The decreased selectivity with the increase of temperature can be ascribed to the side reactions like thermal cracking etc. Though the highest propane conversion is achieved at $640{ }^{\circ} \mathrm{C}$ at the expense of the lowest selectivity, it is not a desirable reaction parameter. Compared the results at $580{ }^{\circ} \mathrm{C}$ with others, the propylene selectivity evidently decreases at other three temperatures. However, the initial propane conversion is only $16.1 \%$ when the reaction is carried out at $580{ }^{\circ} \mathrm{C}$. In general, the reaction

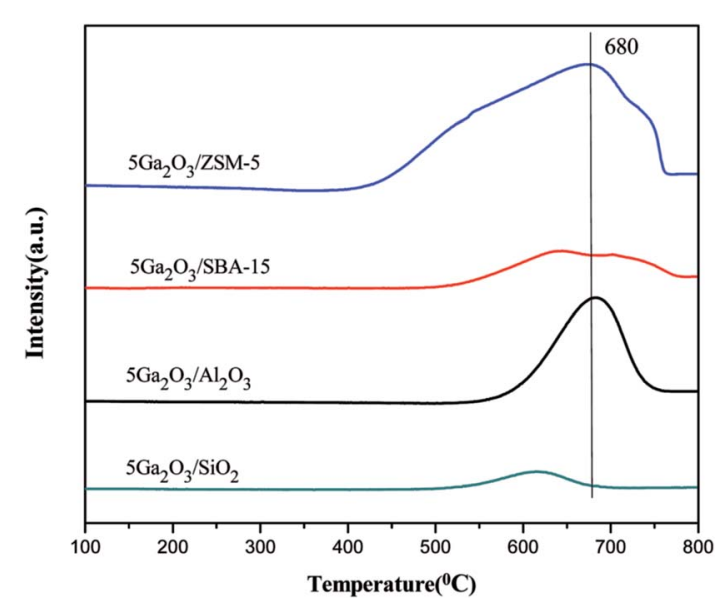

Fig. 12 TPO profiles of the spent catalysts. 


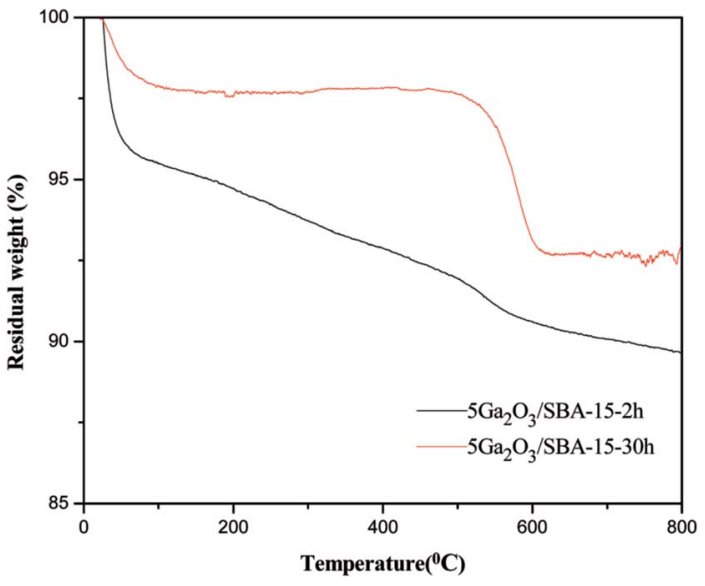

Fig. 13 TG profiles of the spent $5 \mathrm{Ga}_{2} \mathrm{O}_{3} / \mathrm{SBA}-15$ catalysts.

temperature at $600-620{ }^{\circ} \mathrm{C}$ should be the ideal selection to balance the conversion and selectivity of propane dehydrogenation reaction.

As mentioned above, in this work, coke is one main reason to catalyst deactivation..$^{51,52}$ The strong acidity can promote the coke deposition on the catalyst surface. ${ }^{53}$ The total coke amounts of the spent catalysts were analyzed by TPO and TG measurements. It can be seen from Fig. 12 that all the TPO curves of the spent catalysts present one major peak ${ }^{54}$ which is attributed to coke combustion on the catalysts. The peak for $5 \mathrm{Ga}_{2} \mathrm{O}_{3} / \mathrm{SiO}_{2}$ sample presents a relatively lower temperature than the other three catalysts, meaning that the deposited coke is easily combusted. Coke quantitative analysis (Table 6) is in good agreement with TPO results, and the order of coke amount is as follows: $5 \mathrm{Ga}_{2} \mathrm{O}_{3} / \mathrm{ZSM}-5>5 \mathrm{Ga}_{2} \mathrm{O}_{3} / \mathrm{SBA}-15>5 \mathrm{Ga}_{2} \mathrm{O}_{3} / \mathrm{Al}_{2} \mathrm{O}_{3}>$ $5 \mathrm{Ga}_{2} \mathrm{O}_{3} / \mathrm{SiO}_{2}$. The spent $5 \mathrm{Ga}_{2} \mathrm{O}_{3} / \mathrm{ZSM}-5$ catalyst has the largest coke amount $(12.6 \%)$, which coincides with the propylene selectivity in Fig. 8. In this case, as discussed before (Table 2), the $5 \mathrm{Ga}_{2} \mathrm{O}_{3} / Z \mathrm{ZSM}-5$ possesses the quite strong acidity. This should be responsible for the largest amount of coke deposition. When SBA- 15 material is used as the support, the second most coke amount of $5 \mathrm{Ga}_{2} \mathrm{O}_{3} / \mathrm{SBA}-15$ which has the low acidity may owe to the high temperature, Ga species and largest $S_{\mathrm{BET}}$ value. From Table 6, a small amount of coke can be found on pure SBA-15 support, implying that the propane thermal cracking reactions are inevitable during the long-term reaction at such a high reaction temperature $\left(620^{\circ}\right)$. Furthermore, the $\mathrm{Ga}_{2} \mathrm{O}_{3}$-based catalysts are known to be effective catalysts for promoting the selective conversion of light alkanes to aromatics. Many authors agree that the aromatization reaction occurs via a bifunctional mechanism. Not only strong acid sites but also Ga species can enhance the dehydrogenation steps, including the dehydrogenation of alkane, higher olefins, and cycloolefins. Meriaudeau illustrated that the dihydrogen molecule was dissociatively adsorbed on gallium oxide. These might result in producing a large amount of coke precursors during the process of reaction. Moreover, the mesoporous character and high $S_{\mathrm{BET}}$ of SBA-15 make the support have a certain pore volume, which can contain the coke easily. On the contrary, with respect to $5 \mathrm{Ga}_{2} \mathrm{O}_{3} / \gamma-\mathrm{Al}_{2} \mathrm{O}_{3}$ catalyst, without high $S_{\mathrm{BET}}$ value, the coke deposition quickly covers the active sites, and results in an evident decrease in the catalyst activity. When $\mathrm{SiO}_{2}$ material is used as the support, the lowest amount of coke on the $5 \mathrm{Ga}_{2} \mathrm{O}_{3} / \mathrm{SiO}_{2}$ can be found, which is well coincident with the dreadful catalytic activity.

As for $x \mathrm{Ga}_{2} \mathrm{O}_{3} / \mathrm{SBA}-15$ catalysts, the total coke amounts of the spent catalysts are also illustrated in Table 6 . The $5 \mathrm{Ga}_{2} \mathrm{O}_{3} / \mathrm{SBA}-$ 15 and $9 \mathrm{Ga}_{2} \mathrm{O}_{3} / \mathrm{SBA}-15$ catalysts possess the lowest and highest coke content among all the samples respectively, which are in accord with the catalytic performance. Meanwhile, the different reaction time $(2 \mathrm{~h}$ and $30 \mathrm{~h})$ on the nature of coke components are also discussed. As can be seen from Fig. 13, the weight loss between 0 and $300{ }^{\circ} \mathrm{C}$ can be considered as the loss of surface water and water adsorption phase, and the weight loss between 300 and $600{ }^{\circ} \mathrm{C}$ is attributed to the coke combustion on the catalyst surface. It should be noted that the weight loss trend of

Table 7 Comparison of the catalytic performances of different catalysts for propane dehydrogenation reaction

\begin{tabular}{|c|c|c|c|c|c|c|}
\hline Catalysts & $\mathrm{Ga}_{2} \mathrm{O}_{3}$ content $(\mathrm{wt} \%)$ & $T\left({ }^{\circ} \mathrm{C}\right)$ & WHSV $\left(\mathrm{h}^{-1}\right)$ & $X_{\text {propane }}{ }^{a b}(\%)$ & $S_{\text {propylene }}^{a b}(\%)$ & Ref. \\
\hline $\mathrm{Ga}_{2} \mathrm{O}_{3} / \mathrm{MCM}-22$ & 5 & 600 & 0.6 & $57.8(20.6)^{c}$ & $37.5(64.1)^{c}$ & 19 \\
\hline $\mathrm{Ga}_{2} \mathrm{O}_{3} / \mathrm{ITQ}-2$ & 5 & 600 & 0.6 & $30.0(19.3)^{c}$ & $72.0(78.4)^{c}$ & 19 \\
\hline $\mathrm{Ga}_{2} \mathrm{O}_{3} / \mathrm{ZSM}-5$ & 5 & 600 & 0.6 & $76.3(25.0)^{c}$ & - & 18 \\
\hline $\mathrm{Ga}_{2} \mathrm{O}_{3} / \mathrm{TiO}_{2}$ & 5 & 600 & 0.6 & $23.0(3.0)^{d}$ & $85.0(-)^{d}$ & 16 \\
\hline $\mathrm{Ga}_{2} \mathrm{O}_{3} / \mathrm{Al}_{2} \mathrm{O}_{3}$ & 5 & 600 & 0.6 & $33.0(18.0)^{d}$ & $92.0(-)^{d}$ & 16 \\
\hline $\mathrm{Ga}_{2} \mathrm{O}_{3} / \mathrm{MgO}$ & 5 & 600 & 0.6 & $5.3(4.0)^{d}$ & $34.0(-)^{d}$ & 16 \\
\hline $\mathrm{Ga}_{2} \mathrm{O}_{3} / \mathrm{Al}_{2} \mathrm{O}_{3}$ & 5 & 620 & 0.6 & $46.0(15.6)^{c}$ & $95.2(93.1)^{c}$ & This work \\
\hline $\mathrm{Ga}_{2} \mathrm{O}_{3} / \mathrm{ZSM}-5$ & 5 & 620 & 0.6 & $78.1(28.8)^{c}$ & $60.2(86.1)^{c}$ & This work \\
\hline $\mathrm{Ga}_{2} \mathrm{O}_{3} / \mathrm{SiO}_{2}$ & 5 & 620 & 0.6 & $6.7(5.1)^{c}$ & $90.1(91.1)^{c}$ & This work \\
\hline $\mathrm{Ga}_{2} \mathrm{O}_{3} / \mathrm{SBA}-15$ & 5 & 620 & 0.6 & $28.5(22.1)^{c}$ & $92.5(91.6)^{c}$ & This work \\
\hline
\end{tabular}

${ }^{a}$ Note: the given data of $X_{\text {propane }}$ and $S_{\text {propylene }}$ are estimated according to the given curves in the literatures. ${ }^{b}$ The values outside and inside the parenthesis are the data obtained in the initial and terminal times, respectively. ${ }^{c}$ The propane conversion (\%) and corresponding propylene selectivity (\%) after reaction for $8 \mathrm{~h} .{ }^{d}$ The propane conversion (\%) and corresponding propylene selectivity (\%) after reaction for $3 \mathrm{~h}$. 
different samples in the range of $200-600{ }^{\circ} \mathrm{C}$ are markedly different, suggesting that the weight loss of these two samples are caused by the combustion of different coke species. Therefore, it can be concluded that the reaction time may play an important effect on the graphitization degree of coke.

Table 7 displays some reports about the catalytic performances of $\mathrm{Ga}_{2} \mathrm{O}_{3}$-based catalysts for propane dehydrogenation reaction. The initial and final propane conversions and propylene selectivities are collected. As can be seen from Table 7 , the supports of catalyst have great influence on the catalytic performance, especially the propylene selectivity. The previous presented the low propylene selectivity and catalytic stability. However, the $5 \mathrm{Ga}_{2} \mathrm{O}_{3} / \mathrm{SBA}-15$ catalyst in this study displays the excellent catalytic stability accompanied with the relatively high conversion and selectivity, and the catalytic stability is evidently higher than those of the catalysts reported in literatures.

\section{Conclusions}

In this study, the influences of different supports (ZSM-5, SBA15, $\gamma-\mathrm{Al}_{2} \mathrm{O}_{3}$ and $\mathrm{SiO}_{2}$ ) and $\mathrm{Ga}_{2} \mathrm{O}_{3}$ loading on the properties and catalytic performances of supported $\mathrm{Ga}_{2} \mathrm{O}_{3}$ catalysts for propane dehydrogenation reaction were investigated. It can be found that the intrinsic nature of supports and the loading amount could strongly influence the textual properties, surface morphologies, acidic properties, dispersion of Ga species, surface chemical states and coke formation, bringing about the different catalytic performances of the corresponding catalysts. In particular, the strong acid sites of catalyst largely determine the dispersion of Ga species, but the strong acid sites also can induce adverse side reactions. Thus, for $\mathrm{Ga}_{2} \mathrm{O}_{3}$-supported catalysts in propane dehydrogenation reaction, striking an appropriate balance between the roles of strong acid sites in enhancing the reaction activity and that of decreasing the selectivity and stability is essential.

Among the catalysts with different supports, the $5 \mathrm{Ga}_{2} \mathrm{O}_{3} /$ ZSM-5 catalyst shows the best catalytic activity and the lowest catalytic stability, possesses the maximum gallium ions $\left(\mathrm{Ga}^{\delta+}\right.$ cations, $\delta<2$ ), well-dispersed Ga species and strong acid sites. The $5 \mathrm{Ga}_{2} \mathrm{O}_{3} / \mathrm{SBA}-15$ catalyst exhibits the highest catalytic stability, the highest $S_{\mathrm{BET}}$ value and the lowest acidity. The propane conversion only declines $11 \%$ after reaction for $30 \mathrm{~h}$. As for $x \mathrm{Ga}_{2} \mathrm{O}_{3} / \mathrm{SBA}-15$ catalysts, the agglomeration degree of $\mathrm{Ga}$ species gradually increased as the increase of $\mathrm{Ga}_{2} \mathrm{O}_{3}$ loading amount. The $5 \mathrm{Ga}_{2} \mathrm{O}_{3} / \mathrm{SBA}-15$ sample exhibits the highest catalytic performance, possesses the most well-dispersed Ga species and the best structure accompany with the relatively high loading amount, the final propane conversion and propylene selectivity still attain above $17.5 \%$ and $92.0 \%$ after $30 \mathrm{~h}$ propane dehydrogenation reaction at $620{ }^{\circ} \mathrm{C}$.

\section{Acknowledgements}

The research is supported by Science and Technology Commission of Shanghai Municipality (14520502900) and Internation Joint Laboratory on Resource Chemistry (IJLRC).

\section{References}

1 B. V. Vora, Development of Dehydrogenation Catalysts and Processes, Top. Catal., 2012, 55, 1297-1308.

2 F. Cavani, N. Ballarini and A. Cericola, Oxidative dehydrogenation of ethane and propane: How far from commercial implementation?, Catal. Today, 2007, 127, 113-131.

3 A. Dinse, S. Khennache, B. Frank, C. Hess, R. Herbert, S. Wrabetz, R. Schloegl and R. Schomaecker, Oxidative dehydrogenation of propane on silica (SBA-15) supported vanadia catalysts: A kinetic investigation, J. Mol. Catal. A: Chem., 2009, 307, 43-50.

4 T. Ren, M. Patel and K. Blok, Olefins from conventional and heavy feedstocks: Energy use in steam cracking and alternative processes, Energy, 2006, 31, 425-451.

5 F. T. Zangeneh, A. Taeb, K. Gholivand and S. Sahebdelfar, Thermodynamic equilibrium analysis of propane dehydrogenation with carbon dioxide and side reactions, Chem. Eng. Commun., 2016, 203, 557-565.

$6 \mathrm{~J}$. Beckers and G. Rothenberg, Sustainable selective oxidations using ceria-based materials, Green Chem., 2010, 12, 939.

7 G. Siddiqi, P. Sun, V. Galvita and A. T. Bell, Catalyst performance of novel $\mathrm{Pt} / \mathrm{Mg}(\mathrm{Ga})(\mathrm{Al}) \mathrm{O}$ catalysts for alkane dehydrogenation, J. Catal., 2010, 274, 200-206.

8 G. Wang, H. Zhang, H. Wang, Q. Zhu, C. Li and H. Shan, The role of metallic Sn species in catalytic dehydrogenation of propane: Active component rather than only promoter, $J$. Catal., 2016, 344, 606-608.

9 T. A. Peters, O. Liron, R. Tschentscher, M. Sheintuch and R. Bredesen, Investigation of Pd-based membranes in propane dehydrogenation ( $\mathrm{PDH}$ ) processes, Chem. Eng. J., 2016, 305, 191-200.

10 L. Liu, Q.-F. Deng, B. Agula, T.-Z. Ren, Y.-P. Liu, B. Zhaorigetu and Z.-Y. Yuan, Synthesis of ordered mesoporous carbon materials and their catalytic performance in dehydrogenation of propane to propylene, Catal. Today, 2012, 186, 35-41.

11 Y. Ren, J. Wang, W. Hua, Y. Yue and Z. Gao, $\mathrm{Ga}_{2} \mathrm{O}_{3} / \mathrm{HZSM}-48$ for dehydrogenation of propane: Effect of acidity and pore geometry of support, J. Ind. Eng. Chem., 2012, 18, 731-736.

12 L. R. Mentasty, O. F. Gorriz and L. E. Cadus, Chromium oxide supported on different $\mathrm{Al}_{2} \mathrm{O}_{3}$ supports: catalytic propane dehydrogenation, Ind. Eng. Chem. Res., 1999, 38, 396-404.

13 J. G. Eon, R. Olier and J. C. Volta, Oxidative dehydrogenation of propane on $\gamma-\mathrm{Al}_{2} \mathrm{O}_{3}$ supported vanadium oxides, J. Catal., 1994, 145, 318-326.

14 K. Nakagawa, M. Okamura, N. Ikenaga, T. Suzuki and T. Kobayashi, Dehydrogenation of ethane over gallium oxide in the presence of carbon dioxide, Chem. Commun., 1998, 1025-1026.

15 P. Michorczyk and J. Ogonowski, Dehydrogenation of propane to propene over gallium oxide in the presence of $\mathrm{CO}_{2}$, Appl. Catal., A, 2003, 251, 425-433. 
16 B. Xu, B. Zheng, W. Hua, Y. Yue and Z. Gao, Support effect in dehydrogenation of propane in the presence of $\mathrm{CO}_{2}$ over supported gallium oxide catalysts, J. Catal., 2006, 239, 470477.

17 R. Koirala, R. Buechel, F. Krumeich, S. E. Pratsinis and A. Baiker, Oxidative dehydrogenation of ethane with $\mathrm{CO}_{2}$ over flame-made Ga-loaded $\mathrm{TiO}_{2}$, ACS Catal., 2015, 5, 690702.

18 B. Xu, T. Li, B. Zheng, W. Hua, Y. Yue and Z. Gao, Enhanced stability of HZSM-5 supported $\mathrm{Ga}_{2} \mathrm{O}_{3}$ catalyst in propane dehydrogenation by dealumination, Catal. Lett., 2007, 119, 283-288.

19 J. Wang, F. Zhang, W. Hua, Y. Yue and Z. Gao, Dehydrogenation of propane over MWW-type zeolites supported gallium oxide, Catal. Commun., 2012, 18, 63-67.

20 Z. Shen, J. Liu, H. Xu, Y. Yue, W. Hua and W. Shen, Dehydrogenation of ethane to ethylene over a highly efficient $\mathrm{Ga}_{2} \mathrm{O}_{3} / \mathrm{HZSM}-5$ catalyst in the presence of $\mathrm{CO}_{2}$, Appl. Catal., A, 2009, 356, 148-153.

21 B. Zheng, W. Hua, Y. Yue and Z. Gao, Dehydrogenation of propane to propene over different polymorphs of gallium oxide, J. Catal., 2005, 232, 143-151.

22 K. M. Dooley, C. Chang and G. L. Price, Effects of pretreatments on state of gallium and aromatization activity of gallium/ZSM-5 catalysts, Appl. Catal., A, 1992, 84, 17-30.

23 G. D. Meitzner, E. Iglesia, J. E. Baumgartner and E. S. Huang, The chemical state of gallium in working alkane dehydrocyclodimerization datalysts. In situ Gallium $K$-Edge X-ray absorption spectroscopy, J. Catal., 1993, 140, 209-225.

$24 \mathrm{~J}$. A. Biscardi and E. Iglesia, Gallium-loaded zeolites and related systems structure and function of metal cations in light alkane reactions catalyzed by modified H-ZSM5, Catal. Today, 1996, 31, 207-231.

25 A. Ausavasukhi and T. Sooknoi, Tunable activity of [Ga] HZSM-5 with $\mathrm{H}_{2}$ treatment: Ethane dehydrogenation, Catal. Commun., 2014, 45, 63-68.

26 I. Nowak, Effect of $\mathrm{H}_{2}-\mathrm{O}_{2}$ pre-treatments on the state of gallium in $\mathrm{Ga} / \mathrm{H}-\mathrm{ZSM}-5$ propane aromatisation catalysts, Appl. Catal., A, 2003, 251, 107-120.

27 F. Klose, M. Joshi, C. Hamel and A. Seidel-Morgenstern, Selective oxidation of ethane over a $\mathrm{VO}_{x} / \gamma-\mathrm{Al}_{2} \mathrm{O}_{3}$ catalystinvestigation of the reaction network, Appl. Catal., A, 2004, 260, 101-110.

28 A. Qiao, V. N. Kalevaru, J. Radnik, A. Düvel, P. Heitjans, A. S. H. Kumar, P. S. S. Prasad, N. Lingaiah and A. Martin, Oxidative dehydrogenation of ethane to ethylene over $\mathrm{V}_{2} \mathrm{O}_{5} / \mathrm{Al}_{2} \mathrm{O}_{3}$ catalysts: effect of source of alumina on the catalytic performance, Ind. Eng. Chem. Res., 2014, 53, 18711-18721.

29 A. Qiu, E. Li and Y. Fan, Effect of support composition on catalytic performance of PtSn/ZSM-5 catalyst for propane dehydrogenation, Chin. J. Catal., 2007, 28, 970.

30 D. Liu, P. Bai, P. Wu, D. Han, Y. Chai and Z. Yan, Surface chemistry and catalytic performance of chromia/alumina catalysts derived from different potassium impregnation sequences, Appl. Surf. Sci., 2015, 351, 250-259.
31 F. Ying, J. Li, C. Huang, W. Weng and H. Wan, Direct synthesis and superior catalytic performance of $\mathrm{V}$ containing SBA-15 mesoporous materials for oxidative dehydrogenation of propane, Catal. Lett., 2007, 115, 137142.

32 Y. Duan, Y. Zhou, Y. Zhang, X. Sheng, S. Zhou and Z. Zhang, Effect of aluminum modification on catalytic properties of PtSn-based catalysts supported on SBA-15 for propane dehydrogenation, J. Nat. Gas Chem., 2012, 21, 207-214.

33 J. D. Sunseri, W. T. Cooper and J. G. Dorsey, Reducing residual silanol interactions in reversed-phase liquid chromatography: Thermal treatment of silica before derivatization, J. Chromatogr. A, 2003, 1011, 23-29.

34 R. Srivastava, D. Srinivas and P. Ratnasamy, Sites for $\mathrm{CO}_{2}$ activation over amine-functionalized mesoporous $\mathrm{Ti}$ (Al)SBA-15 catalysts, Microporous Mesoporous Mater., 2006, 90, 314-326.

35 M. León, E. Diíaz, S. Bennici, A. Vega, S. Ordónez and A. Auroux, Adsorption of $\mathrm{CO}_{2}$ on hydrotalcite-derived mixed oxides: sorption mechanisms and consequences for adsorption irreversibility, Ind. Eng. Chem. Res., 2010, 49, 3663-3671.

36 B. Solsona, T. Blasco, J. M. López Nieto, M. L. Peña, F. Rey and A. Vidal-Moya, Vanadium oxide supported on mesoporous MCM-41 as selective catalysts in the oxidative dehydrogenation of alkanes, J. Catal., 2001, 203, 443-452.

37 M. A. Smith, A. Zoelle, Y. Yang, R. M. Rioux, N. G. Hamilton, K. Amakawa, P. K. Nielsen and A. Trunschke, Surface roughness effects in the catalytic behavior of vanadia supported on SBA-15, J. Catal., 2014, 312, 170-178.

38 Y. Zhang, Y. Zhou, M. Tang, X. Liu and Y. Duan, Effect of La calcination temperature on catalytic performance of PtSnNaLa/ZSM-5 catalyst for propane dehydrogenation, Chem. Eng. J., 2012, 181, 530-537.

39 X. Liu, W.-Z. Lang, L.-L. Long, C.-L. Hu, L.-F. Chu and Y.-J. Guo, Improved catalytic performance in propane dehydrogenation of $\mathrm{PtSn} / \gamma-\mathrm{Al}_{2} \mathrm{O}_{3}$ catalysts by doping indium, Chem. Eng. J., 2014, 247, 183-192.

40 C. H. Bartholomew, Mechanisms of catalyst deactivation, Appl. Catal., A, 2001, 212, 17-60.

41 C. Yu, H. Xu, Q. Ge and W. Li, Properties of the metallic phase of zinc-doped platinum catalysts for propane dehydrogenation, J. Mol. Catal. A: Chem., 2007, 266, 80-87.

42 L. Brabec, M. Jeschke, R. Klik, J. Novakova, L. Kubelkova, D. Freude, V. Bosáček and J. Meusinger, Various types of Ga in MFI metallosilicates: characterization and catalytic activity, Appl. Catal., A, 1998, 167, 309-320.

43 A. Ausavasukhi, T. Sooknoi and D. E. Resasco, Catalytic deoxygenation of benzaldehyde over gallium-modified ZSM-5 zeolite, J. Catal., 2009, 268, 68-78.

44 R. Carli, C. L. Bianchi, R. Giannantonio and V. Ragaini, Low temperature reduction of gallium in a $\mathrm{Ga}_{2} \mathrm{O}_{3} / \mathrm{HZSM}-5$ catalyst, J. Mol. Catal., 1993, 83, 379-389.

45 S. E. Collins, M. A. Baltanás, J. L. G. Fierro and A. L. Bonivardi, Gallium-hydrogen bond formation on gallium and gallium-palladium silica-supported catalysts, J. Catal., 2002, 211, 252-264. 
46 B. M. Reddy, I. Ganesh, E. P. Reddy, A. Fernández and P. G. Smirniotis, Surface characterization of $\mathrm{Ga}_{2} \mathrm{O}_{3}-\mathrm{TiO}_{2}$ and $\mathrm{V}_{2} \mathrm{O}_{5} / \mathrm{Ga}_{2} \mathrm{O}_{3}-\mathrm{TiO}_{2}$ catalysts, J. Phys. Chem. B, 2001, 105, 6227-6235.

47 N. Rane, A. Overweg, V. Kazansky, R. Vansanten and E. Hensen, Characterization and reactivity of $\mathrm{Ga}^{+}$and $\mathrm{GaO}^{+}$ cations in zeolite ZSM-5, J. Catal., 2006, 239, 478-485.

48 E. J. M. Hensen, M. García-Sánchez, N. Rane, P. C. M. M. Magusin, P.-H. Liu, K.-J. Chao and R. A. Van Santen, In situ Ga $K$ edge XANES study of the activation of Ga/ZSM-5 prepared by chemical vapor deposition of trimethylgallium, Catal. Lett., 2005, 101, 79-85.

49 M. Guisnet and N. S. Gnep, Aromatization of propane over GaHMFI catalysts. Reaction scheme, nature of the dehydrogenating species and mode of coke formation, Catal. Today, 1996, 31, 275-292.

50 P. Meriaudeau and M. Primet, FTIR study of hydrogen adsorption on $\alpha-\mathrm{Ga}_{2} \mathrm{O}_{3}$, J. Mol. Catal., 1990, 61, 227-234.
51 B. K. Vu, M. B. Song, I. Y. Ahn, Y.-W. Suh, D. J. Suh, J. S. Kim and E. W. Shin, Location and structure of coke generated over Pt-Sn $/ \mathrm{Al}_{2} \mathrm{O}_{3}$ in propane dehydrogenation, J. Ind. Eng. Chem., 2011, 17, 71-76.

52 Y. Zhang, Y. Zhou, L. Wan, M. Xue, Y. Duan and X. Liu, Effect of magnesium addition on catalytic performance of PtSnK $/ \gamma$ $\mathrm{Al}_{2} \mathrm{O}_{3}$ catalyst for isobutane dehydrogenation, Fuel Process. Technol., 2011, 92, 1632-1638.

53 Y. Zhang, Y. Zhou, J. Shi, S. Zhou, Z. Zhang, S. Zhang and M. Guo, Propane dehydrogenation over PtSnNa/La-doped $\mathrm{Al}_{2} \mathrm{O}_{3}$ catalyst: effect of La content, Fuel Process. Technol., 2013, 111, 94-104.

54 Y. Zhang, Y. Zhou, L. Wan, M. Xue, Y. Duan and X. Liu, Synergistic effect between $\mathrm{Sn}$ and $\mathrm{K}$ promoters on supported platinum catalyst for isobutane dehydrogenation, J. Nat. Gas Chem., 2011, 20, 639-646. 